\title{
PHOTOGRAPHIC REPRESENTATIONS OF 'TRUTH': \\ THE HISTORY AND CONTEMPORARY PRACTICE \\ OF PHOTOGRAPHIC NARRATIVE TABLEAUX
}

\author{
by
}

\section{D'Arcy L. J. White}

BJ, Carleton University, Ottawa, Ontario, 1993

\begin{abstract}
A thesis project
presented to Ryerson University, Toronto, Ontario, Canada and

George Eastman House International Museum of Photography and Film, Rochester, New York, United States of America
\end{abstract}

in partial fulfillment of the

requirements for the degree of

Master of Arts

in the Program of

Photographic Preservation and Collections Management

Toronto, Ontärio, Canada, 2010

(C) D'Arcy L. J. White, 2010 


\section{Author's Declaration}

I hereby declare that I am the sole author of this thesis or dissertation.

I authorize Ryerson University to lend this thesis or dissertation to other institutions or individuals for the purpose of scholarly research.

I further authorize Ryerson University to reproduce this thesis or dissertation by photocopying or by other means, in total or in part, at the request of other institutions or individuals for the purpose of scholarly research. 
PHOTOGRAPHIC REPRESENTATIONS OF 'TRUTH': THE HISTORY AND CONTEMPORARY PRACTICE OF PHOTOGRAPHIC NARRATIVE TABLEAUX

\section{D'Arcy L. J. White}

Master of Arts, 2010

Photographic Preservation and Collections Management

Ryerson University, Toronto, Ontario in coordination with George Eastman House International Museum of Photography and Film, Rochester, New York

\section{Abstract:}

This thesis explores the history of photographic narrative tableau from the Victorian era, through modernism, postmodernism, and postpostmodernism examining, as case studies, the contemporary work of Patrick Nagatani and Gregory Crewdson. It illustrates how this genre evolved over time, noting technological, social and cultural influences affecting artists and their work. It includes a discussion of contemporaneous photographic theory and criticism, and illustrates how staged narrative tableau photographs have a paradoxical relationship to the problematic concept of truth.

Topics discussed include artifice, the uncanny, paradox, the contemporary sublime, and the aesthetics of seduction; the complicit gaze, antinarrative, and the role of the viewer; the use of language, words, and signs; fact, myth, truth, and the (re)creation of history; theatricality, melodrama, and metaphor; allegory, simulation, simulacra, reality, and the real. 


\section{Acknowledgements}

I would like to thank George Eastman House staff Alison Nordström, Curator of Photographs, Jamie Allen, Assistant Curator of Photographs, and Joe Struble, Archivist, for their encouragement, persistence, and assistance during the initial formulation of my ideas.

To my thesis advisor, Blake Fitzpatrick, I would like to extend my humble gratitude for his wisdom, patience, guidance, and constant encouragement, as well as his most thorough and insightful feedback.

To all the members of my family, especially my mother Patricia White, my father Michael White, and my sisters Rae White and Tanya McConnell, as well as my peer Sarah Fay, my thanks for your patience, encouragement, good humour, love, and support. I could not have achieved this milestone without any of you. 
To my sister Rae,

who has always shared my love of storytelling. 
FIGURES

INTRODUCTION

LITERATURE SURVEY

1980s Sources.

3

1990-2000s Sources.

5

Chapter

ONE

A BRIEF HISTORY OF PHOTOGRAPHIC NARRATIVE

TABLEAU (FROM THE VICTORIAN ERA THROUGH

MODERNISM)............................................................ 8

The Victorian Era .................................................. 8

Pictorialism............................................................. 12

The Great Depression, World Wars, and

Documentary Photography ...................................... 13

Advertising Photography........................................ 14

Surrealism and Neo-surrealism............................. 15

Modernism............................................................. 17

TWO

NARRATIVE TABLEAU IN THE POSTMODERN ERA:

PATRICK NAGATANI AS A CASE STUDY...................... 21

Defining Postmodernism (1960-1989)................. 21

Technological, Social, and Cultural

Considerations....................................................... 23

The Work of Patrick Nagatani as a Case Study... $\quad 26$

The Issue of Truth.................................................... 37

T.HREE

NARRATIVE IABLEAU IN THE POST-POSTMODERN

ERA: GREGORY CREWDSON AS A CASE STUDY........ 40

Defining Post-Postmodernism (1990-present)... 40

Technological, Social, and Cultural

Considerations.

44

The Work of Gregory Crewdson as a Case

Study

46

The Issue of Truth.................................................. 62

CONCLUSION

64

BIBLIOGRAPHY

66 


\section{FIGURES}

1. "The Two Ways of Life" by Oscar Gustave Rejlander.............................. 10

2. "Fading Away" by Henry Peach Robinson............................................... 11

3. "Trinity Site, Jornada del Muerto, New Mexico, 1989" by Patrick Nagatani.

4. "The Evening News, Native American Pueblo Dwelling, New Mexico, $1990 "$ by Patrick Nagatan

5. "Radon Gas, Elementary School Classroom, Albuquerque, New Mexico, 1990" by Patrick Nagatani

6. "Untitled (nude woman in trailer)" 2004 by Gregory Crewdson......... 50

7. "Untitled (north by northwest)" 2004 by Gregory Crewdson.............. 54

8. "Untitled (bed of roses)" 2005 by Gregory Crewdson............................ 56

9. "Untitled (woman at the vanity)" 2004 by Gregory Crewdson............ 56

10. "Untitled (Forest Clearing)" Summer 2006 by Gregory Crewdson..... 58 


\section{Introduction}

Narrative Tableau ${ }^{1}$ is an important genre in contemporary photographic art practice. It has a history that was well documented in the 1980 s when it came back into fashion after a period of absence from the art scene during the modernist era. But since the 1980 s only one survey book has attempted to trace the genre from its inception in the early days of photography through modernism, postmodernism, and post-postmodernism. ${ }^{2}$

This paper proposes to examine photographic narrative tableau through key periods in history, with an emphasis on the contemporary. It will illustrate how narrative tableau has evolved and changed over time, noting technological, social and cultural influences affecting narrative tableau artists and their work in the various eras. It will also consider contemporaneous photographic theory and criticism surrounding such work. Most importantly, it will examine how, ultimately, all these staged narrative tableau photographs, from the earliest days right up until today, pivot around the medium's relationship to the problematic concept of truth.

Chapter One will trace the history of the narrative tableau photograph from Victorian times through the modern era. Chapter Two will examine the narrative tableau photograph in the postmodern era, with the work of Patrick

1. For the purposes of this paper I define photographic narrative tableau as photographs employing human actors, props, and sets in photographs preconceived and staged by the photographer.

2. Editor Lori Pauli's 2006 Acting the Part: Photography as Theatre does not define postmodernism or post-postmodernism, but does address contemporary photography in its last chapter "The Artful Disposition: Theatricality, Cinema, and Social Context in Contemporary Photography." This chapter considers the work of such artists as Jeff Wall, Cindy Sherman, and Gregory Crewdson, amongst others, comparing contemporary staged photography to that produced in the 1980 s. 
Nagatani as a case study. And Chapter Three will examine the narrative tableau photograph in the post-postmodern era, with the work of Gregory Crewdson as a case study. 


\section{Literature Survey}

\section{0 s Sources}

Books published on staged photography in the 1970 s and 80 s were numerous, particularly if you include catalogues of exhibitions on staged photography. But towards the end of the decade enough time, thought, and words had been dedicated to the subject to allow a survey of the practice through these key texts.

Anne H. Hoy's 1987 Fabrications: Staged, Altered, and Appropriated Photographs identifies staged photographs as postmodern ${ }^{3}$, stating tableau photography did not exist from 1910 until the 1960 s. $^{4}$ She lists five categories of the staged photograph ${ }^{5}$, describing each in depth in its own chapter, replete with a historical perspective, and a list, including images, of contemporaneous practitioners. Hoy is the earliest survey book I found that categorized the various forms of staged photography.

Andy Grundberg and Kathleen McCarthy Gauss' 1987 Photography and Art: Interactions Since 1946 takes addifferent approach, structuring their study chronologically. Working from modernism through to postmodernism, Grundberg and Gauss examine surrealism, pop art, experiments with process, conceptual art, and constructivism looking at early influences and

3. Defined by Hoy as "antagonistic" to modernism. See "Modernism" in Chapter One for a more in-depth discussion and definition of photographic modernism.

4. Anne H. Hoy, Fabrications: Staged, Altered, and Appropriated Photographs (New York: Abbeville Press, 1987), 7-8.

5. These categories are tableau; portraiture; still life constructions; appropriation of images and words; and print manipulation and photo-collage. 
contemporary practices. In her chapters "Breaking the Mold: Experiments in Technique and Process" and "In the Studio: Construction and Invention" Gauss elucidates some of the technical, social, and commercial reasons for changes in photographic tastes and styles prevalent in the modernist period. Editor Michael Köhler's 1989 Constructed Realities: The Art of Staged Photography combines the techniques of both the above-mentioned books, beginning with an historical overview bridging modernism to postmodernism via surrealism and conceptual photo art, followed by a detailed examination of a comprehensive group of five categories of staged photography. ${ }^{6}$ These categories are subtly refined versions of Hoy's published two years earlier, and proved to be more comprehensive and useful. Köhler examines technological innovations that led to changes in photographic objects and imagery, which he uses to define postmodernism. He concludes that staged photography was the postmodernist ${ }^{7}$ way of dealing with photography's representational accuracy, previously seen as an obstacle to photography's acceptance in the art world. ${ }^{8}$ Thus, Köhler signals the dilemma surrounding staged photography and photographic truth, which is explored in further depth in this thesis.

6. These categories are self-presentations (considers roles and identities); narrative tableaux (several human actors play scenes from life, history, myth or fantasy as directed by the artist); miniature stages (tableaux reconstructions in miniature using dolls and toys); still lifes (objects); and photo-sculptures and installations (large-scale staged scenes with objects).

7. Köhler defines postmodernism as a strong opposition to modernism. See "Defining Postmodernism (1960-1989)" in Chapter Two of this thesis for a more in-depth discussion and definition of photographic postmodernism.

8. Michael Köhler, ed., Constructed Realities: The Art of Staged Photography (Zurich: Edition Stemmle, 1989), 44-45. 


\section{0-2000s Sources}

Editor Lori Pauli's 2006 National Gallery of Canada exhibition catalogue Acting the Part: Photography as Theatre is a contemporary survey of staged photography. Composed of four essays by four different authors, the book examines the theatrical, or narrative photograph from three different perspectives and periods in history, from a study of the Victorian album by Marta Weiss, to an examination of staged photography and modernism by Ann Thomas, and finally a look at contemporary photography by Karen Henry. The book makes both detailed analyses and broad observations, but it suffers from the lack of a summative conclusion, perhaps a condition of writing about artists and work still being made.

In a lengthy introductory essay "Setting the Scene" Pauli identifies three roles played by photographers staging images - actor, artist, and storyteller - but acknowledges these categories are neither rigid nor exclusive. Pauli expressly narrows the scope of the book by excluding portraiture, constructions, and fabrications based solely on scenes or objects, which makes it more in keeping with my interests. And she selects only works with "theatrical performance" and "narrative content," which I believe embody the narrative tableau category. Pauli produces a comprehensive overview of the history of tableau photography, referencing early Victorian social influences and making insightful observations about the role of technology. In her analysis of the storyteller role, Pauli examines allegory, metaphor, naturalism, and narrative or storytelling in staged tableau photography from the Victorian era to present day. 
A purely historical view of staged photography, Weiss' "Staged Photography in the Victorian Album" illustrates how the Victorians did not make distinctions between staged and documentary images in the same way we do today. I feel this historical perspective is important and relevant to understanding contemporary narrative tableau photography.

Thomas' "Modernity and the Staged Photograph, 1900-1965" covers familiar territory, but argues all modernist photography (art, advertising, and photojournalism) used staging to construct narrative. This is an interesting contradiction to thinking in the 1980 s, which posited staged photography as postmodern opposition to straight modernism. However, it is worth noting that Thomas included commercial work in his argument, which was likely not considered in the writing of the 1980s, which was only concerned with fine art photography.

Henry's "The Artful Disposition: Theatricality, Cinema, and Social Context in Contemporary Photography" considers the work of Jeff Wall, Cindy Sherman, and Gregory Crewdson, amongst others. She compares contemporary staged photography tc that produced in the 1980 s, discussing concepts of social relevance, broken allegory, and the uncanny.

François Brunet's 2009 Photography and Literature, as the title implies, looks for a connection between photography and the literary. Of course staged photography fits within Brunet's purview. His approach is a chronological historical examination, but only the fourth chapter, "The Literature of Photography", is relevant to this paper. It provides a concise but somewhat cursory overview of the history of narrative photography, which is 
perhaps more adequately covered in the above-mentioned books. It does, however, address the concept of narrative more directly and explicitly than do the other books.

Full publication information for all books cited in the literature survey (along with the balance of the thesis) is available in the bibliography, pages 66 to 69 . 


\section{Chapter 1}

\section{A Brief History of Photographic Narrative Tableau (From the Victorian Era through Modernism)}

I have decided, for the purposes of this paper, to focus on narrative tableau. Narrative tableau is a genre that is strongly represented through almost all periods of photography's storied history, and has an interesting relationship to notions of truth in photography, which will be the focus of this paper.

In this first chapter I will briefly outline the history of narrative tableau photography, highlighting examples from the earliest days of photography through the modern era, noting, where relevant, how these relate to the idea of truth in photography. This chapter and these examples will provide grounding for the following chapters' more contemporary examples and concerns, allowing contrast and comparisons to be made.

\section{The Victorian Era}

In the Victorian era dressing up and posing in tableaux was a common parlour game. And early photographic tableaux were seen as popular entertainment. But they were also charged with high-minded aesthetic aspirations. The first three decades took their cue from history painting, manipulating subjects, and moulding facts just as artists did in paint. ${ }^{9}$ This may in part have contributed to the Victorian claim that photography was a

9. The dominant style of academic painting in the nineteenth century, history painting drew from classical and Christian history and mythology, depicting religious, mythological, historical, literary and allegorical subjects, painting scenes with narrative content. The genre often employed interpretive liberties to construct its moral or intellectual messages. 
potential form of high art, but the fact remained that people were put off by the medium's clarity of detail and fact. ${ }^{10}$

Naturalism and storytelling were not in opposition to Victorian photographers, who used props, lighting, costumes and gestures in an effort to make their images more realistic. There was less concern about distinctions between staged and documentary style photographs in the Victorian era than there is now. In her essay "Staged Photography in the Victorian Album," Marta Weiss notes that the practice followed a continuum, with staged photographs of hired actors directed by a photographer at one end, and wealthy patrons dressed in costumes photographed by hired photographers at the other end, with amateur photographers falling somewhere in the middle, producing collaborative works. Posing for and making imagery was, in the Victorian era, a form of social interaction, paired with a love of drama and dressing up, as reflected by the popularity of charades, tableaux vivant and amateur theatricals. ${ }^{11}$

Carter Ratcliff notes in his article "Tableau Photography: From Mayall to Rodan, Its Roots and Its Reason" that in the mid-1840s and 50s David Octavius Hill and Robert Adamson posed and shot scenes by Sir Walter Scott with friends dressed as monks, knights, and bards. ${ }^{12}$

In 1857 Oscar Gustave Rejlander produced the large ( $16 \times 31$ inches) "The Two Ways of Life" (fig. 1) as a composite from approximately thirty

10. Carter Ratcliffe, "Tableau Photography: From Mayall to Rodan, Its Roots and Its Reason," Picture, 1981, 5-6. 83-84.

11. Lori Pauli, ed., Acting the Part: Photography as Theatre (London: Merrell, 2006),

12. Ratcliffe, 5. 


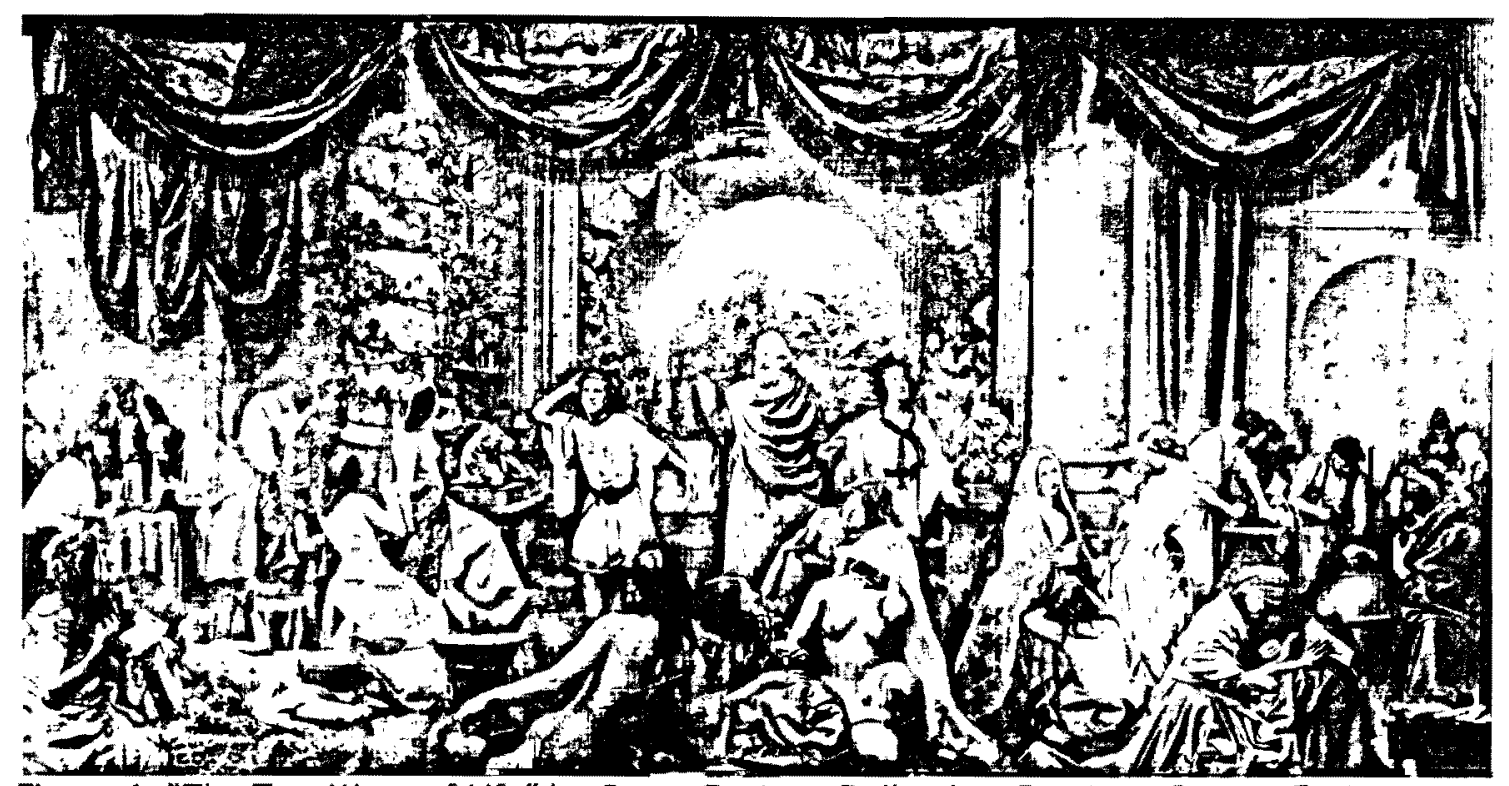

Figure 1. "The Two Ways of Life" by Oscar Gustave Rejlander. Courtesy George Eastman House International Museum of Photography and Film.

negatives. The piece was intended and created as a moral, artistic, and technical achievement. The linearity and composition of the piece was influenced by theatre and the Victorian pastime tableau vivant. ${ }^{13}$ It is staged in the manner of a theatrical stage with curtains above and on each side, with a painted backdrop. The composite nature of the image allowed Rejlander to play the role of two of the characters, including the central Sage figure and one of the gamblers. He hired tableau vivant actors for the other characters. Rejlander copied other works of art and paintings as staged tableaux because he thought rendering human forms with photographic accuracy would help teach rendering to artists.

\section{In 1858 Henry Peach Robinson produced "Fading Away" (fig. 2) using} five negatives and double exposures. The public, convinced of the tableau's

13. French for 'living picture,' the term tableau vivant describes a practice of dressing up in costumes and posing without speaking or moving. Performed by both amateurs in their drawing rooms, and professionals on stage, it was used for entertainment and education, often reenacting paintings. 


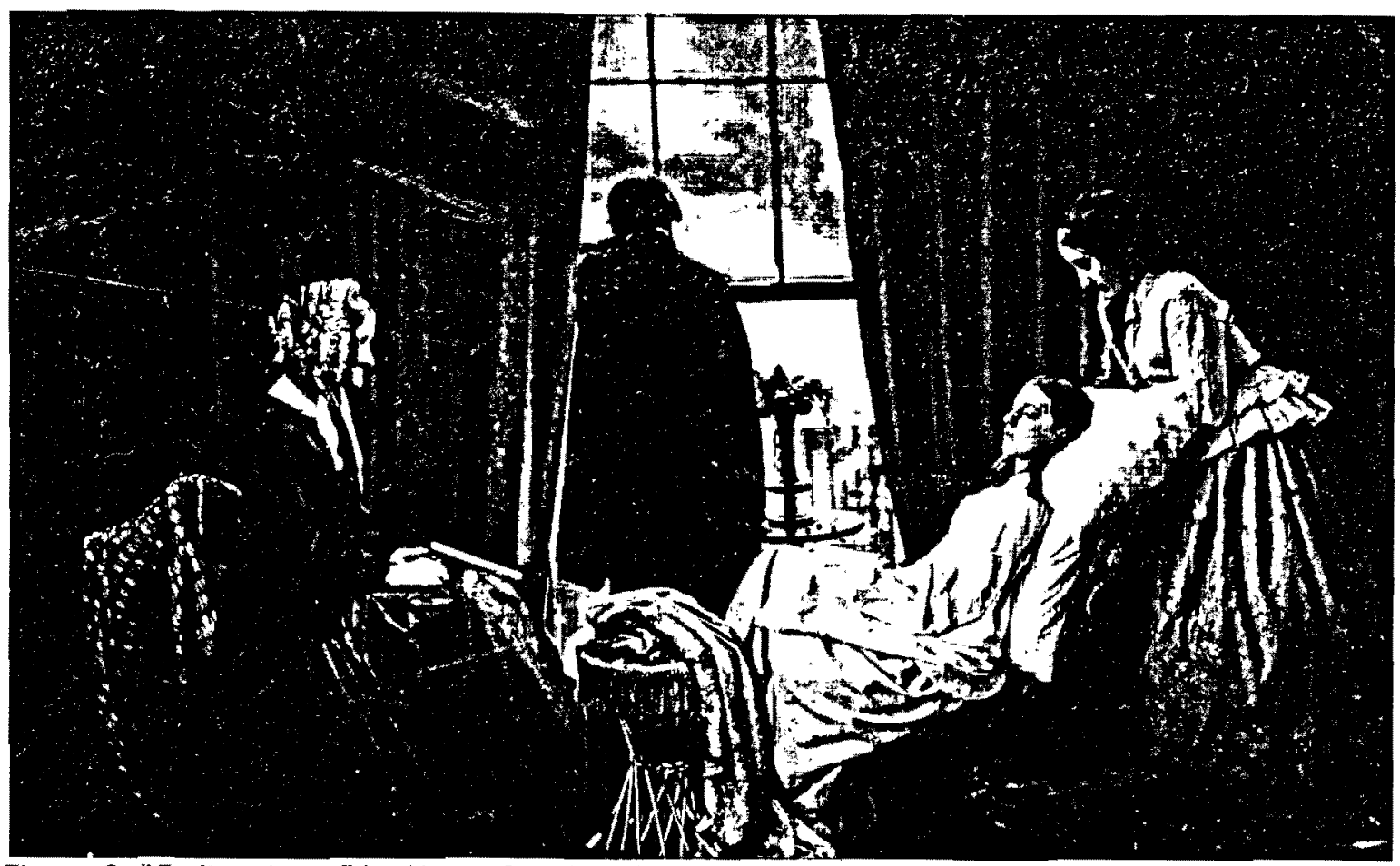

Figure 2. "Fading Away" by Henry Peach Robinson. Courtesy George Eastman House International Museum of Photography and Film.

reality, was angered by this public display of private sorrow. But when, in 1860 , he explained his process to the Photographic Society of Scotland they were angered by the perception that they had been decelved.

Photographers like Henry Peach Robinson, O. G. Rejlander, and later, F. Holland Day all attracted controversy because of their use of montage, as well as impersonations, even though this was seen as fully acceptable in painting. ${ }^{14}$ Pauli sums up the difference, stating:

Because photography reflects the physical world more directly than does painting, manipulation of the image may seem tantamount to deception. The photographic portrayal may appear all too real, or it

14. A. D. Coleman, "The Directorial Mode: Notes Toward a Definition," in Light Readings: A Photography Critic's Writings (New York: Oxford University Press, 1979), $254 \mathrm{n}$. Coleman notes a public controversy arose in 1888 between Henry Peach Robinson and Peter Henry Emerson. Emerson argued for purism in photography, by which he meant no interference, use of multiple negatives, or retouching (except for the insertion of fake clouds to compensate for limitations of the medium). Interestingly Emerson's methodology was called naturalism, whereas Robinson's was called realism. 
may be insufficiently real, making it hard for viewers to suspend their disbelief and accept the representation of fiction in a photograph. ${ }^{15}$

These early concerns and debates about deception and veracity in photography, brought to the forefront by the use of staged photographs, are seen in every era of photographic history. And yet, in Victorian times, staged photography was not seen as problematic in the same way as it would be viewed later, because of the technology available at the time. Large, unwieldy cameras, with long exposures, requiring long poses naturally led to the photographer taking on the role of director.

\section{Pictorialism}

Pictorialists, like F. Holland Day, Gertrude Käsebier, and later William Mortensen, were influenced by Greek drama, medieval Passion plays and mime of Commedia dell'arte, creating images that conveyed religious, moral, political, and social values, using pose and gesture as language.

Many late pictorialists, including Mortensen and Outerbridge, moved to Hollywood where their skill with lighting and story telling was welcome. Film influenced their work, instilling it with glamour and melodrama, ultimately blurring the lines between art and commercial work. Dismissed in the 1930 s as a "purveyor of vulgar melodrama," Mortensen and others were criticized for "ignoring the inherent properties of the medium in favor of images that are more appropriate to the stage, the movies, or painting. ${ }^{\prime 16}$ Here we see

15. Pauli, 26-27.

16. Ratcliffe, 14. 
the beginning of a modernist backlash on the pictorial, which is discussed in more detail later in this chapter.

\section{The Great Depression, World Wars, and Documentary Photography}

Both World War I and World War II pushed the development of technology and the dispersal of images, which led to advances in film speed, allowing for the semblance of the documentary truth of a "stolen moment." After these changes in technology, including handheld, faster cameras with roll film that brought about the evolution of the snapshot, staged photographs seemed inferior. Speed led to immediacy and the idea of a captured unmanipulatable moment that was perceived as more truthful. The time taken to construct narrative tableau photographs led to the thinking that they were less truthful and more artificial. A desire for the "immediate" and "lack of illusion" meant that theatrical photography was seen as a "bourgeois diversion."17

By the mid-twentieth century narrative tableau photography had fallen almost completely "out of favour" as cinema came into its own, a medium "more powerfully able to convey the narrative dimension of time. ${ }^{18}$ As photography was used more and more frequently as a tool for science and journalism, staging was "increasingly regarded with a mixture of skepticism and suspicion."19 In 1930 Edward Weston summed up the anti-narrative
17. Pauli, 138.
18. Ibid., 16.
19. Ibid., 15. 
sentiment of the times stating "Photography is too honest a medium, direct and uncompromising, to allow for subterfuge. ${ }^{\prime 20}$

The onset of the Great Depression also created a demand for documentary photography, and the aesthetic climate of the time favoured straight photography. But it is now a well-known fact that Farm Security Administration photographer Arthur Rothstein posed models for his famous photograph "A Dust Storm, Cimarron County, Oklahoma" in 1936.

Paradoxically, even at the height of photojournalistic and documentary realism, staging photographs, the medium's capacity for narrative, deception, and veracity remained issues, though well hidden and buried beneath anti-narrative rhetoric popular at the time.

\section{Advertising Photography}

At the beginning of the 1920 s advertising began to display strong narrative content, which by the 1950 s became dominant. ${ }^{21}$ Commercial advertising photography borrowed from the art world in the 1920 s and 30 s using photomontage, photocollage, porspective, and narrative tableau. Photography was seen to add "truth and verisimilitude" to commercial endeavours. Ann Thomas summed up the importance and role of photographic narrative tableau in advertising in her essay "Modernity and the Staged Photograph, 1900-1965," stating:

Its seductive crispness and illusionistic quality in conjunction with the narrative tableau permitted the creation of a complete visual scenario 319.

20. Edward Weston, "Photography-Not Pictorial," Camera Craft 37, no. 7 (1930):

21. Pauli, 15, 34. 
in which consumer objects and life-style references could be inserted. Readers of advertisements would be able to project their own dreams and hopes into these apparently ideal set-ups. In addition, the photograph wielded authority simply by virtue of its supposed neutrality. ${ }^{22}$

Edward Steichen, Paul Outerbridge Jr., Lejaren à Hiller, amongst others (many of whom had experience in theatre and film), employed models, lighting and incorporated gesture from silent films into their commercial work. By the 1940 s movies had taken the place of paintings as inspiration for photographic tableaux, either "as a model, enemy or target of the tableau-maker's irony." ${ }^{23}$

\section{Surrealism and Neo-surrealism}

In 1924 Andre Breton called for a new method called "dream photography" in his First Surrealist Manifesto. Surrealism as a movement explored emotion, psychology, myth, and fantasy through the allegorical, spiritual, and psychological. It drew from sources in literature, painting, and film.

Surrealists liked tableau vivant ${ }^{24}$ because they found it useful in exploring fantasy and dream imagery, as well as narrative sequencing. They juxtaposed unlikely objects, strange places, and played with scale to create mystery, threat, ambiguity, and allure. These works inspired later

22. Pauli, 124.

23. Ratcliffe p.12

24. For a definition of tableau vivant see p.10n13 of this thesis. 
photographers William Mortensen, Paul Outerbridge, and Lejaren à Hiller, as well as television, fashion photography, and commercial film.

From the 1940 s to 60 s, late American surrealist photographers Clarence John Laughlin, Jerry Uelsmann, and Duane Michals worked with narrative tableau, utilizing allegory and metaphor. ${ }^{25}$ Uelsmann constructed his images with layered negatives (like antecedents Robinson and Rejlander). These photographic artists sought to transcend photographic truth, and create symbolic or interpretive imagery by repudiating the medium's "supposedly obligatory documentary role." They worked against the established aesthetic and purpose of the documentary, and challenged what was seen as the essence of photography-its "credibility as a simulacrum, a bona fide representation of the truth. ${ }^{26}$

In the chapter "Surrealism, Symbolism, and the Fictional Photograph" Andy Grundberg states:

Seeking to suggest a different reality, many photographers attacked through their imagery the idea of the certitude and 'objectivity' of photographic evidence. Paradoxically, the success of their work revolved upon its exploitation of the common, a priori acceptance of the photographic image as true. ${ }^{27}$

25. Allan Sekula, "On the Invention of Photographic Meaning," in Photography Against the Grain: Essays and Photo Works, 1973-1983 (Halifax: The Press of the Nova Scotia College of Art and Design, 1984), 15, 21. Sekula distinguishes metaphor and metonym as dichotomous terms he likens to symbolist vs. realist, or art photography vs. documentary photography. Essentially he states metaphor denies the iconic level of a photograph, instead defining meaning on the level of abstraction. He says, "In photography this compulsion requires an incredible denial of the image's status as report."

26. Andy Grundberg and Kathleen McCarthy Gauss, Photography and Art: Interactions Since 1946 (New York: Abbeville Press, 1987), 45-46.

27. Ibid., 45. 
As Grundberg notes, the success of photographic surrealism and neosurrealism hinged on photography's supposed inherent faithfulness to truth and representation. Much more than any other medium, photography allowed surrealists to challenge ideas of reality.

\section{Modernism (1945-1959)}

In his article "Crisis of the Real" Andy Grundberg states photography was not art if it merely described. In order to seem legitimate photography needed to "invent the photographic." For photographic modernists of the post-war period, this was achieved, Grundberg argues, by drawing on Alfred Stieglitz's American purism and László Moholy-Nagy's European experimental formalism. ${ }^{28}$

In Art and Photography David Campany notes:

Art photography had always been wary of the popular character of the medium. Its aesthetic aspirations could be so easily thwarted by the colossal weight of its popular cultural 'other', with its base indistinctness, simplicity, blank objectivity, industrial standards, entertainment value and disposability. ${ }^{29}$

Campany states modernist art photography sought to define itself by "aesthetic conservatism," formalism and introversion, "bound up with an idea of both artist and medium possessed of a coherent and given core." The modernist concern of medium specificity and purity led to a "purging of all those things extraneous to the essence." Focus, detail, framing, perspective,

28. Andy Grundberg, Crisis of the Real: Writings on Photography, 1974-1989, Writers and Artists on Photography (New York: Aperture Foundation, 1990), 14.

17.

29. David Campany, ed., Art and Photography (London: Phaidon Press Limited, 2003), 
shutter speed and tonality, were seen as photography's unique, inherent internal properties. ${ }^{30}$

In Constructed Realities: The Art of Staged Photography Michael Köhler provides a succinct and useful definition of modernism in photography. He suggests that visually modernism was concerned with issues of realism and objectivity seen at that time as inherent in photography. In more detail, modern photographers were to find not invent; make no alterations to a subject; render a photograph objectively, clearly, sharply, and true to form and detail; perform no manipulation of the negative in the darkroom; print with technical perfection, rich in tonal range, with no manipulation of the print; and execute creativity through view, focal length, and exposure time, avoiding painterly and graphic effects. ${ }^{31}$

As Max Kozloff notes in "Through the Narrative Portal," modernist photography could have symbolic meanings, but no narrative. Narrative was seen as the tool of middlebrow art and media, including movies, fiction, songs, theatre, television, comics, and advertising. ${ }^{32}$

As Kathleen McCarthy Gauss notes in Photography and Art:

Interactions Since 1946 there was, as of yet, no market established for fine art photography, so $8 \times 10$ and $11 \times 14$ inch prints were produced as they were cheaper and more intimate. Also, the highly skilled level of craft and technique expected in photographic detail and resolution contributed to the

30. Campany, 18-19.

31. Köhler, 18.

32. Max Kozloff, "Through the Narrative Portal," Artforum, April 1986, 86. 
popularity of contact printing and smaller, rather than larger,

enlargements. ${ }^{33}$ Black-and-white prints were the norm at a time when gelatin silver paper was readily available and standardized, whereas colour materials were technically difficult. And modernists shunned older processes, used by pictorialists.

In Fabrications: Staged, Altered, and Appropriated Photographs Anne Hoy argues there was no tableaux photography from 1910 to the 1960 s. $^{34}$ Given the observations above on pictorialism, advertising photography, surrealism and neo-surrealism we recognize this statement as false. But it is true that tableau photography grew to be highly disregarded as a means of expression in photographic art with the onset of modernism. Modernist photographers' pursuit of objectivity, with their 'find not create' edict, felt the practice of narrative tableau photography ignored the medium's inherent properties. Narrative tableau was seen at best as symbolic or interpretive, and at worst as subterfuge and dishonest. There was a concern its use blurred the line between art and commercial photography, and that it undermined photography's "credibility as a simulacrum." ${ }^{35}$ It was felt film was a more appropriate medium for narrative. The popularity of staged photography continued its decline in the 1940 s and 50 s. So much so, in fact, that photographers would claim staged images as spontaneous (e.g.

33. It is worth noting contact printing, by its nature, made print manipulation more unlikely, and was therefore seen as more truthful than enlargements, which could more readily use burning, dodging and other darkroom print manipulation techniques. Contact printing also heightened truth-value because of its one-to-one relationship of indexicality between paper and negative.

34. Hoy, 8.

35. Grundberg and Gauss, 45-46. 
Weegee's "The Critic", and Robert Doisneau's "The Kiss at the Hôtel de Ville").

But when the sway of modernism was over, and postmodernism was in full swing contradicting all of modernism's valued notions, MoMA curator and modernist hold-out John Szarkowski stated, in 1975, that photography was the "perfect tool for visual exploration and discovery, but a rather clumsy one for realizing the inventions of pure imagination. ${ }^{\prime 36}$ I hope, in the next chapter on postmodernism, to prove that actually, it could be both.

36. John Szarkowski, "A Different Kind of Art: To its new public, photography seems to present not only dumb facts but also personal visions," Photography, New York Times 1923Current file, April 13, 1975

http://ezproxy.lib.ryerson.ca/login?url=http://proquest.umi.com.ezproxy.lib.ryerson.ca/pqdwe b?did $=355241902 \&$ sid $=1 \& \mathrm{Fmt}=10 \&$ clientId $=10120 \& \mathrm{RQT}=3098 \mathrm{VName}=\mathrm{HNP}$ (accessed June $23,2010)$. 


\section{Chapter 2}

\section{Narrative Tableau in the Postmodern Era: Patrick Nagatani as a Case Study}

Whereas modernist art photography "explored and reiterated the voice of the medium itself," postmodern photographic narrative could be said to speak with a "plethora of voices. ${ }^{137}$ In the postmodern era the medium specificity of modernism gave way to a multiplicity of styles, voices and meaning in an effort to more readily reflect the contemporary social experience. As Karen Henry says in her essay "The Artful Disposition: Theatricality, Cinema, and Social Context in Contemporary Photography" theatrical photography was used to reflect on social experience, with the best work "able to reach beyond its own artifice and remain relevant to social circumstänces."

In this chapter I will explore narrative tableau photography in the postmodern era, looking more closely at the work of Patrick Nagatani as a case study.

\section{Defining Postmodernism (1960-1989)}

As in the last chapter on modernism, Köhler provides a succinct and useful definition of postmodernism in photography. He notes postmodernism blurred the distinction between high versus pop culture, and the hierarchy of art mediums. Invention, fabrication, arrangement, construction,

37. John S. Weber, "Narrative Dimensions in Recent North American Photography," European Photography, October/November/December 1985, 18.

38. Pauli, 134. 
appropriation, print and negative manipulation, as well as an understanding that a lack of technical finesse in negatives and prints did not speak to the quality of the work characterized photography in the postmodern era.

The postmodern era was punctuated by an insecurity (which was created by visual media) that questioned reality and what was real. "Camera media" images-from photography, film, television, and video-created a secondary reality. This secondary reality began receiving more attention than "empirical reality" and was preferred over experience as a way to comprehend the lived world. Once judged by its "conformity" to reality, instead, reality was now judged based on these media images. ${ }^{39}$ The level of image saturation in society led to a need to be "seduced" by images that "outdo reality through excessiveness-as in advertising and movies." Staged "media events" or images became "managed" like fiction, with suspense, drama and happy endings, while infotainment, movies and advertising also adhered to "laws of fiction" while simulating reality..$^{40}$

Köhler places the division of modernism and postmodernism after World War II. Further, he divides the postmodern era into three stages, which he defines as the early or pioneer phase (1960-80), the heroic phase (1970-80), and the heyday phase (1980-89). He defines the early phase as characterized by a blending of production methods between painting and photography, as practiced by Robert Rauschenberg and Andy Warhol. During the heroic phase postmodernism became an established fine art practice with view of itself.

39. A key example of this is the influence of advertising imagery on western society's 40. Köhler, 22-23. 
celebrated artists such as Christian Boltanski, William Wegman, David

Levinthal, Les Krims, and Duane Michals. By the heyday phase the conceptual concerns of the seventies were exhausted and of secondary concern. Attention turned to an "aesthetics of seduction"41 and a playful use of deception, where clues were given to break the illusion in order to "disillusion or to deconstruct it. ${ }^{\prime 42}$

Finally, Köhler notes postmodernism must be defined by its relationship to its predecessor, even though it was a relationship of strong opposition. In Köhler's view postmodernism had to "demolish" the old before it could move forward. ${ }^{43}$ He saw 1980 s staged photographs as "slaughtering the sacred cow of Modernism." ${ }^{14}$

\section{Technological, Social, and Cultural Considerations}

Television replaced photography as the main carrier of cultural messages in the 1960s, leaving photography more open to use for selfexpression with subjective and interpretive work. Freed from the "burden of truth" formerly attached to the medium, "the very authenticating power of

41. Köhler, 23. Köhler defines the "aesthetics of seduction" as a need, driven by the level of image saturation in society, to be seduced by images that "outdo reality through excessiveness-as in advertising and movies".

42. Ibid., $24,38$.

43. Ibid., 45. In a long list Köhler outlines how postmodernism destroyed the myth of artistic genius by eliminating original motifs through appropriation of themes and subjects; destroyed the elite status of art by use of the popular and trivial; destroyed the sublime by using kitsch and other forms of poor taste; destroyed the prohibition of illusion by use of representational narrative themes; destroyed asceticism, or the "economy of effect," and simplicity with "verbosity" and an "abundance" of motifs; destroyed purism by mixing media and genres; and finally, destroyed the "avant-garde pathos of modern art" with pastiche, parody, travesty, melodrama, and comedy.

44. Ibid., 45. 
photography was turned on its head by its new alignment with storytelling, playacting or masquerade. ${ }^{m 5}$

Also beginning in the 1960 s, significant technological advances in photography played a direct role in the working methodology, as well as the physical appearance of the work of narrative tableau artists.

Cibachrome paper first appeared on the market in 1967, Ektachrome paper in 1968, Polaroid SX-70 film in 1974, and $20 \times 24$ inch Polaroid film in 1980. Two large frame Polaroid cameras were made available to artists (one at the Polaroid headquarters in Cambridge, MA and the other in Amsterdam) in 1980, with another following (in New York) in 1985. These cameras were conducive to tableau constructions because they were studio-bound, and required previsualization.

Photographers in the mid-1970s were technically more adept, employing medium and large format cameras, and colour material that was printed by labs, thus increasing image size.

By 1972 amateur and hobby photographers' use of colour materials equaled their use of black and white. By 1976 the use of colour was three times more that of black and white. ${ }^{46}$

But, even then, many in the photographic art world were still working with ideas of modernist authenticity, so the desire for the representational remained strong and the use of colour was "understated." These artists saw strong, contrasty, saturated colours as "a vision of horror" associated with

45. François Brunet, Photography and Literature, Exposures, edited by Mark HaworthBooth and Peter Hamilton (London: Reaktion Books, 2009), 105.

46. Köhler, 37. 
amateur photography and advertising. The "New Color Photographers" almost only used Ektachrome paper as it had the richest scale of colour available in colour paper. ${ }^{47}$

However, photographers working with staged photography in the 1980 s preferred Cibachrome paper and the $20 \times 24$ inch Polaroid film because they provided more saturated colour. The paper had "hard" colour, rich in contrast, and a "hard" shiny metallic surface. The film had "deep" saturated tones that created a "velvety smoothness." Overall, the effect was "more intense and elegant but as a result more artificial" than the Ektachrome material. The effect suited the artificial and staged, and was often further intensified with coloured lights and brightly coloured props, sets, and costuming to "shrill tonal effect." Closer to advertising photography, these photographers no longer sought "distinction through distancing" but rather "distinction through outdoing." 48

Instead of the modernist, purist, conceptual, analytical, objective, appeal to reason, photography was now a postmodern eclectic, with a spectacular appeal to sensuality and visual lust, the "beauty of illusion," and the "aesthetics of entertainment." ${ }^{49}$

By 1989 cultural critic Andy Grundberg was calling photography a "cultural artifact" that had found refuge in the world of art and museums. ${ }^{50}$

47. Köhler, 37.

48. Ibid.

49. Ibid.

50. Grundberg, 219. 


\section{The Work of Patrick Nagatani as a Case Study}

Patrick Nagatani was selected for this case study because he typifies the use of narrative tableau by photographers of the era, and because his work raises important questions related to photographic truth.

Nagatani was trained as a designer and worked on sets in Hollywood in the 1970s, where he built special effects models for science fiction films such as Bladerunner and Close Encounters of the Third Kind, learning state-of-theart filmmaking and model building techniques. This experience developed his "fanatical" attention to arranging every little detail for the camera, as well as the theatrical nature of his work.

From 1983 to 1989 he collaborated with painter Andrée Tracey creating vibrant cross-media tableaux for the $20 \times 24$ Polaroid camera. Cited influences of this collaboration included set advertising photography, pop paintings of the 1960s, and political editorial cartoons. Nagatani has said about his collaboration with Tracey, "Our photographic scenarios served as the perfect arena in which to explore our themes of disaster beyond our control. In this blend of fact and fiction, the threat was (and still is) so great that it seemed unreal, the reality so awful it was/is impossible to comprehend." 51

In 1987 Nagatani moved from Los Angeles to Albuquerque, New Mexico to accept a teaching position at the University of New Mexico. There

51. Center for Creative Photography, University of Arizona, "Patrick Nagatani at The Center for Creative Photography," Traditional Fine Art Online, Inc., http://www.tfaoi.com/aa/2aa/2aa234.htm (accessed May 29, 2010). 
he began what was initially intended as a photographic/literary collaboration with poet Joel Weishaus exploring the atomic heritage of his new home.

Ultimately resulting in forty tableau photographs in a series entitled "Nuclear Enchantment", Nagatani's work incorporated collage, installation art, miniature scale models, life-size sculptures, painted sets, and actors. He often applied coloured oils to his photographs. With a working methodology similar to that worked out with Tracey in the 1980s, Nagatani broke down the divisions between media, and blurred the line between the real and artificial, and between photographic fact and fiction. Working in a mode that borrowed from advertising and set design, he combined live figures with previously photographed cardboard cutouts, painted or hand coloured photographic backdrops, and props held up with visible monofilament supports.

Unabashed Artifice and the Aesthetics of Seduction

Köhler explains that work like Nagatani's was typical of staged photography in the 1980 s because it cpenly showed the staging. Earlier works tended to hide the staging, as the photographers were "unwilling to abandon the causal link to reality. ${ }^{152}$ Hoy, however feels the "unabashed artifice," in which set construction is apparent, and the actors used are amateur, presents an intentionally incomplete illusion to show both the maker and the made-a record of the performance that also reveals the

52. Köhler, 8. 
aesthetics, culture, and psyche of the artist. Hoy believes this generates both irony, and appeal. ${ }^{53}$

In his chapter "Camera Culture in a Postmodern Age" Grundberg describes a self-consciousness that "promotes an awareness of photographic representation, of the camera's role in creating and disseminating the 'commodities' of visual culture." According to Grundberg, this technique aimed to present stereotypes of mass culture for questioning, positioning the viewer as a critic instead of consumer. ${ }^{54}$ Again this returns to the notion of photographic veracity and representations of truth.

Evidence of construction is visible throughout Nagatani's work. In "Trinity Site, Jornada del Muerto, New Mexico, 1989" (see fig. 3) the landscape backdrop is obviously a painted scene, several of the figures appear as cardboard cutouts, and at least four nylon monofilament support lines are clearly visible. Exaggerated colour dominates the image, with both the backdrop and the skin of the human figures coated in a glaring, hot red. Of course, the colour implies radioactivity (commonly referred to as 'hot')the invisible effectively made visible-both on the land, and the unwitting people who visit the site.

53. Hoy, 9.

54. Grundberg and Gauss, 208. 


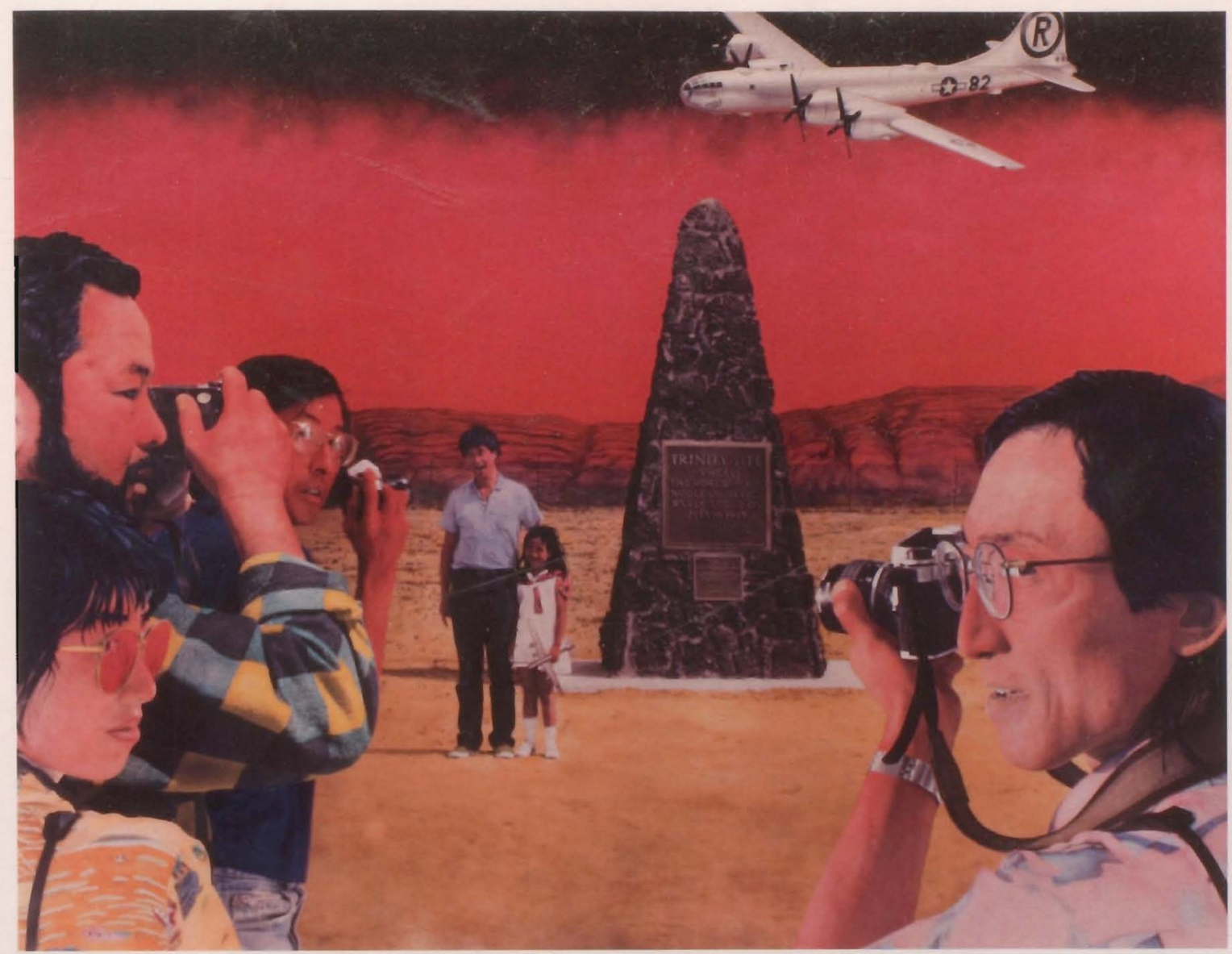

Figure 3. "Trinity Site, Jornada del Muerto, New Mexico, 1989", (c) Patrick Nagatani. Courtesy George Eastman House International Museum of Photography and Film.

In "The Evening News, Native American Pueblo Dwelling, New Mexico, 1990" (fig. 4) the five native American family members are obviously inserted into the scene because their colour is muted compared to that of the rest of the scene and they appear grainy, almost as though they were images cut out of a newspaper. The television screen in the background is also oddly coloured, intentionally drawing the eye to it. Again Nagatani is drawing attention to media's various roles in the creation and dissemination of the nuclear myth. 


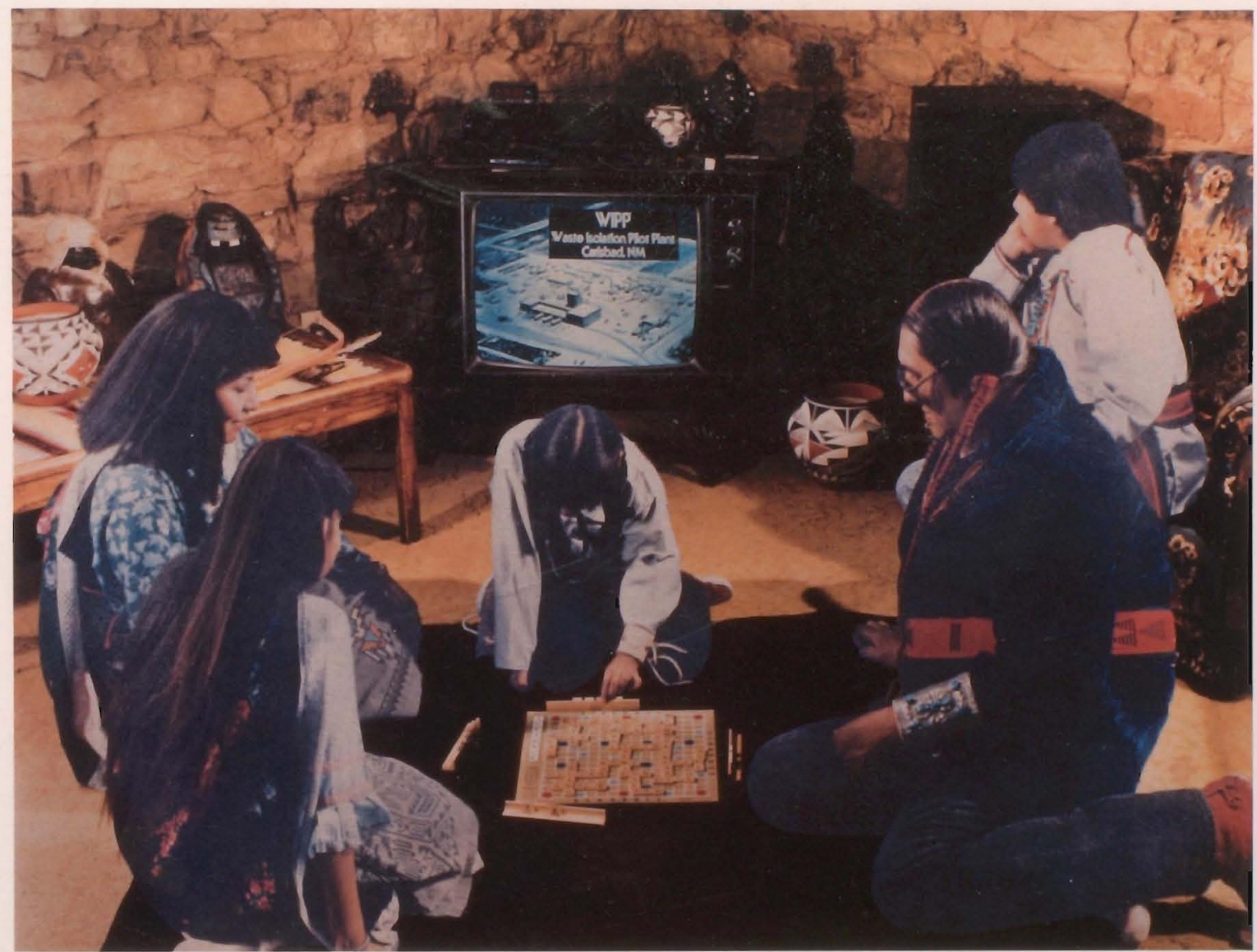

Figure 4. "The Evening News, Native American Pueblo Dwelling, New Mexico, 1990", (c) Patrick Nagatani. Courtesy George Eastman House International Museum of Photography and Film.

In "Radon Gas, Elementary School Classroom, Albuquerque, New Mexico, 1990" (fig. 5) the carefully framed photograph contains evidence of the photographer's presence by way of a lighting stand and cords intentionally included around the edges of the frame, along the right side, and bottom left corner. Again, as with much of Nagatani's work, colour plays a dominant role. A toxic green permeates the room, hugging the walls, floor, and teacher seated at the front of the room, while encircling but not actually enveloping the children seated in the foreground. As with all the examples cited, the unabashed artifice is intentional, used to make the invisible visible, 
to encourage the viewer to question what is seen or shown, or conversely not seen or shown in photographs.

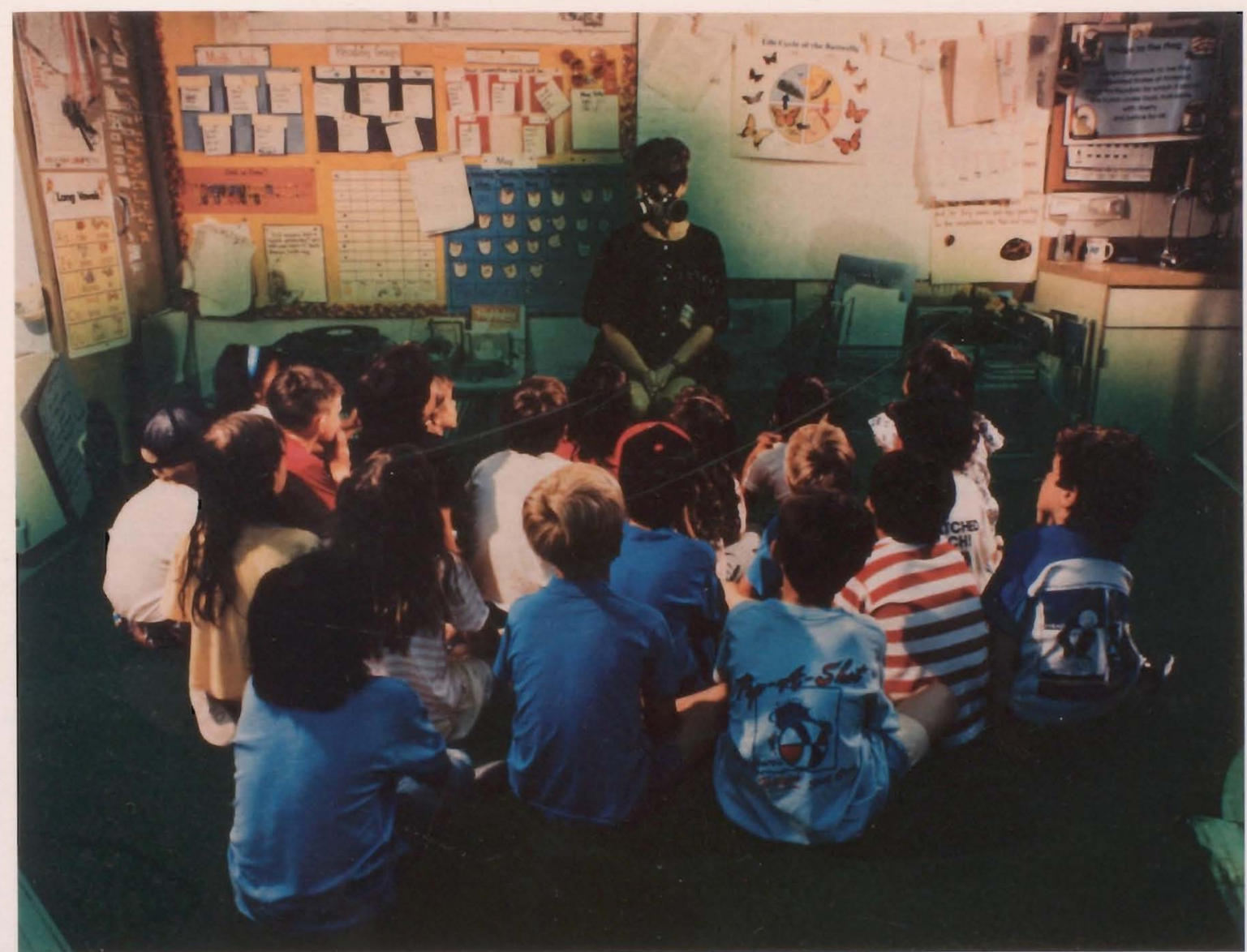

Figure 5. "Radon Gas, Elementary School Classroom, Albuquerque, New Mexico, 1990", (c) Patrick Nagatani. Courtesy George Eastman House International Museum of Photography and Film.

By including his tools of trade along the edge of the frame, Nagatani illustrates the photographer's role in editing and selecting what is shown within, and what is cut out of the photographic frame, and hints at the construction of all photographic images, not just his own. At the same time, the more obvious noxious green 'gas' painted in to the scene implies the risks encroaching on 'the innocent' (the children in the image) unrestrained by 'knowing adults' in positions of leadership, instruction, and responsibility (the gas-mask clad teacher) who turn a blind eye to the dangers inherent in 
nuclear industries. Furthermore, the teacher's gas mask covered face makes her an anonymous figure that stares out at the viewer thus implicating all adults with the complicit gaze.

The Complicit Gaze and The Role of the Viewer

In several of Nagatani's images the subject in the photograph gazes directly at the viewer. Kozloff explains this gaze as designed to reveal the viewer's "complicity in the production of content," by allowing him or her to actively "resist, deflect, or criticize" the allotment of this role. ${ }^{55}$

"Trinity Site, Jornada del Muerto, New Mexico, 1989" is a prime example of this (fig. 3). Three figures in the frame (including Nagatani himself) hold cameras up to their faces to photograph the monument before them, but instead of looking through their viewfinders, glance back over their shoulders engaging the viewer as a participant. A fourth figure has what is presumably a camera strap slung over her shoulder, and also turns her gaze back towards the viewer. By placing the viewer within the picture plane, presumably as another camera toting tọurist, or at the very least as witness to the same, Nagatani draws attention to society's and the artist's use of the camera in creating narrative, history, and the commodity of memories, whether they be tourist snapshots, or works of commercial art. In this example Nagatani addresses several issues. More than just a critique of atomic tourism, though that is certainly at play in his work, he is asking viewers to take responsibility for what they read, see and hear. But he is also

55. Kozloff, 97. 
asking the viewer to recognize his or her own apathy as a form of complicity in the blind worship and passive acceptance of the prevailing myths generated by the nuclear industry.

Language, Words, and Signs

Nagatani's captions, and use of words and signs within his images also illustrates a "working awareness that photographic meaning is a culturally mediated construction" and not a universal language. Used in such a manner, language appears "not as a stylistic gambit, but as a method of expanding the scope of references available to the artist, a way to speak about themes only vaguely approachable with photos alone." ${ }^{156}$

The title of "Trinity Site, Jornada del Muerto, New Mexico, 1989" (fig. 3) provides viewers with precise location details, a key, should one be so inclined, to further research. Further information is gleaned from the sign on the monument in the centre of the image, which reads "Trinity Site, where the world's first nuclear device was exploded on July 16, 1945." Once read, considered, and understood, that sign brings new understanding of the significance of this simple stone monument, and its connection to the Japanese figures, and model planes populating the image. In this example, both the plane in the child's hand and the plane suspended in the sky are models of the Enola Gay, the plane used to drop the atomic bomb on Hiroshima.

56. Weber, 17. 
The title of "The Evening News, Native American Pueblo Dwelling, New Mexico, 1990" (fig. 4) provides less information, but the image itself is full of wordplay, most notably in the form of a Scrabble board positioned in the lower centre of the frame, which spells out the words radioactive; after; heed; hero; island; piling; big; bomb; atomic; real; ton; uranium; laguna; we; cow; over; red; life; seep; and hope. Two words, gnome and Nagasaki, both draw additional attention as each holds a blank tile which must be filled in by the viewer, involving the viewer in this game of words and the piecing together of their meanings. The implications of some of these words are obvious, others less so. The viewer is left to guess at the words' connections, or again, to pursue further knowledge on his or her own. A television screen in the upper centre of the frame displays the words "WIPP Waste Isolation Pilot Plant Carisbad, NM," again suggesting a narrative not fully implied solely by the image of a native American family seated on the floor playing Scrabble.

In this image Nagatani demonstrates Native American families' complicity with the nuclear industry in two ways-as both aware of nuclear issues, based on the words on the Scrabble board, and yet, at the same time, inattentive to the news on the television screen. In the introductory essay of the nuclear series' monograph "A Hot Iron Ball He Can Neither Swallow Nor Spit Out: Patrick Nagatani, Nuclear Fear and the Uses of Enchantment" Eugenia Parry Janis notes that only a child watches the news 
report on the nuclear waste disposal plant while the rest of the family distances itself from the issues "by relegating them to abstractions. ${ }^{157}$

In a final example "Radon Gas, Elementary School Classroom, Albuquerque, New Mexico, 1990" (fig. 5) Nagatani's title confirms viewers' suspicions regarding the nature of the painted green 'gas' in the image, and locates the generic classroom scene within New Mexico. Again, signs within the image give further insight into the artist's message, with a sign illustrating the life cycle of a butterfly over the left shoulder of the teacher seated, facing the viewer, and a "Pledge to the Flag" sign in the top right corner of the frame. The presence of the painted green "radon gas" within this otherwise innocuous elementary classroom makes the presence of these signs ominous, and their suggested meanings carry more weight.

Facts, Myths, and Truths: (Re)Creating History

The loss of faith in any master narrative, especially written, is a symptom of the postmodern condition Nagatani addresses in his work. Nagatani says, "I hope to challenge us to examine the ways in which photography creates, recreates, or supports a particular history. ${ }^{158}$

Janis succinctly sums up Nagatani's nuclear work, stating:

The many images within a single work act as vectors that point toward collisions of ideas which he calculates to look ridiculous in order more effectively to tell the truth; this is in contrast to the multitude of

57. Eugenia Parry Janis, "A Hot Iron Ball He Can Neither Swallow Nor Spit Out: Patrick Nagatani, Nuclear Fear and the Uses of Enchantment," in Nuclear Enchantment: Photographs by Patrick Nagatani (Albuquerque: University of New Mexico Press, 1991), 38.

58. Center for Creative Photography, University of Arizona. 
reading he has done in the press, which, despite its good faith, seems to him to perform the opposite function. ${ }^{59}$

Weber seems to agree with Janis, explaining that contemporary use of narrative in art is "often part of an attempt to speak truthfully, if not factually, and to speak of truths which are often obscured by mountains of factual, quantified data and standardized information." ${ }^{60}$

Facts and figures, which often appear in textual form, are difficult to represent visually. Nagatani's work attempts to synthesize copious amounts of research conducted through traditional news media (newspapers and magazines), corporate publicity brochures, and public information hearings. Many of his sources are carefully detailed in the monograph's introductory essay, but as an artist Nagatani rewrites this overabundance of information visually, complicating the issues by exposing stories that can't be so easily summarized. Nagatani's images function as deconstructions of the myths generated by facts and figures.

In his essay "Crisis of the Real" Andy Grundberg states "Images constitute what we are" and "constitute all of what we know." Postmodernism did away with the belief in authenticity of experience and became instead an "assertion of the finiteness of the visual universe. ${ }^{161}$

Nagatani attempts to show what no longer exists (events in the past), is invisible to the eye (e.g. radioactivity), or has no concrete or visible presence (facts, figures, and military secrets). As with history painters of the

59. Janis, 28.

60. Weber, 16.

61. Grundberg, 10-11, 16. 
past, Patrick Nagatani and other narrative tableau photographers of the postmodern era sought, through the pre-digital means at their disposal, to tell a story in a single image. Using postmodern narrative tableau techniques such as unabashed artifice, the complicit gaze, language, words, and signs, Nagatani translated his near incomprehensible mass of accumulated facts and data into visual "truths" with multiple layers of meaning. The result is an attempt to create or rewrite an almost absent visual history, to make visible the invisible, and to reinterpret and problematize facts in a visual and comprehensible way.

\section{The Issue of Truth}

Köhler addresses the issue of postmodern narrative tableau photographs and truth in a statement that seems to address Nagatani's work, stating "the sense of these cheerful, ironic and at the same time unsettling and frightening pictures is not immediately clear is quite probably a function of the impossibility of gaining a 'true' picture of reality today without succumbing to some deception or manipulation. ${ }^{162}$ He later continues, "There can no longer be established truths but instead only contradictory mixtures of appearance and reality, fact and fiction." ${ }^{63}$

Pauli also notes theatricality is "debated in relation to the purity of representation in capturing the essence of experience. ${ }^{164}$ As Brunet explains,
62. Köhler, 8.
63. Ibid., 39.
64. Pauli, 134. 
"The aesthetic and epistemological model of (truthful) representation that underlay the former etymology has by and large yielded to a definition of art as (subjective, historical, economic, social) production. ${ }^{\prime \prime 5}$ It is thought this change in direction in the postmodern production of art, particularly with the use of narrative tableau, would ultimately result in something closer to truth than the earlier modern model was able to create.

As Nagatani did with his photographs, postmodern photographers working in narrative tableau learned how to deal with photography's representational accuracy by using simulation-exploiting the accuracy of the camera to lend the unreality of objects the appearance of reality. ${ }^{66}$ This was accomplished with a variety of pre-digital tools, including collage, installation art, miniature scale models, life-size sculptures, painted sets, and actors, as well as tableau techniques described above (unabashed artifice, the complicit gaze, and the use of language, words, and signs). By utilizing such tools postmodern artists demonstrated that the image beheld was more 'authentic' than perceived reality. ${ }^{67}$ Nagatani's obviously staged photographs clearly signal their own unreality, but, based as they are on nuclear history, offer a critique of a reality hidden behind nuclear myths.

As Kathleen Edwards says in Acting Out: Invented Melodrama in Contemporary Photography, staged photographs that exist "between the historicity of the record and the fiction of the set" are "fictive terrains" that

65. Brunet, 143.

66. Köhler, 44.

67. Kathleen A. Edwards, Acting Out: Invented Melodrama in Contemporary Photography (Iowa City: University of Iowa Museum of Art, 2005), 15. 
are located in "credible spaces, feasible circumstances, and fantastic possibilities," where the artist, model and viewer are all "implicit collaborators in the search for and critique of meaning. ${ }^{168}$

In 1989 , on the cusp of what was perceived to be yet another change of direction in the continuous ebb and flow of art production, history, theory, and criticism, Köhler asked how far photographic art could take the "aesthetics of seduction" and "beauty of illusion" before it again became traditional realism $?^{69}$ I hope, in my next chapter, to address this and other questions surrounding what is, at present, being called the post-postmodern.

68. Edwards, 16.

69. Köhler, 44. 


\section{Chapter 3}

\section{Narrative Tableau in the Post-Postmodern Era: Gregory Crewdson as a Case Study}

In the post-postmodern era theatricality, the relationship between the artist and audience, and the position of art in consumer culture are all accepted notions. Pauli sums up the era, stating:

The artist is free to develop a sophisticated language of symbolic imagery that resonates with social circumstances. Creating tableaux is a central strategy, evoking the multiple and complex, sometimes conflicting, associations of elements in the images. In the process, the images themselves have become larger and more colour-saturated, more cinematic. ${ }^{70}$

How then, in the post-postmodern era, does the use of narrative tableau relate to the representation of truth in photography? And how does this era differ from the representation of truth exemplified by the work of Patrick Nagatani in the postmodern era? In this chapter I endeavour to answer these questions through examination of the images and working methodologies of Gregory Crewdson.

\section{Defining Post-Postmodernism (1990-present)}

Defining post-postmodernism is a difficult challenge. Established and respected cultural theorists have created various definitions, but don't address cultural production outside of television and film. Fine art, and more specifically, fine art photography, does not seem to be in their purview. Finding a photographic critical theorist who has written about the post-

70. Pauli, 149. 
postmodern era has proved next to impossible.

One example of such thinking is noted British scholar Alan Kirby who first published his notions on what he called pseudo-modernism in the essay "The Death of Postmodernism and Beyond" in the British journal Philosophy Now, in 2006. He later expanded these ideas, at the same time changing his terminology to digimodernism, in the 2009 book Digimodernism: How New Technologies Dismantle the Postmodern and Reconfigure our Culture. His exploration of digimodernist cultural production includes videogames, film, television, radio, music and literature. Photography does not even appear in the index. ${ }^{71}$ Kirby's basic premise states all pseudo-modern (or digimodern) cultural production must be created wholly or in part by the recipient (Kirby argues the passive term viewer no longer applies) who "phones, clicks, presses, surfs, chooses, moves, downloads." Such cultural production, Kirby argues, is amnesiac, entirely of the present with no past or future. ${ }^{72}$

Crewdson's work obliquely addresses this condition, and will be discussed later in this chapter under the sub-heading "Antinarrative and The Role of the Viewer."

Although her definitions are highly general Paula B. Hartness' master's thesis, "Po Pomo: The Post Postmodern Condition," remains one of the only critical sources which attempted to define photographic post-postmodernism. She suggests the term post-postmodernism began to appear in the 1990 s to

71. Alan Kirby, Digimodernism: How New Technologies Dismantle the Postmodern and Reconfigure our Culture (New York: Continuum International, 2009), bk.

72. Alan Kirby, "The Death of Postmodernism And Beyond," Philosophy Now, 2006, under "What's Post Postmodernism?" and "Clicking In the Changes,"

http://www.philosophynow.org/issue58/58kirby.htm (accessed July 16, 2010). 
distinguish newer work from its postmodern predecessors. As with any era or movement within art history, theory, and criticism, there is no clear boundary or line of demarcation between any two periods. There are, after all, some (including Clement Greenberg and Fredric Jameson) who argue against distinctions made between modernism and postmodernism, claiming that postmodernism is just another manifestation of modernist art. "The most frustrating and perhaps disturbing aspect of Po PoMo is that it is so difficult to distinguish from Postmodernism," says Hartness. "This art movement, which began in the mid to late 1980 s, is so firmly tied to Postmodernism that it could almost be mistaken for its twin." ${ }^{73}$

As examples of this confusion, Hartness cites Jeff Koons, and Cindy Sherman as artists that have a foot in each of the two eras, stating "Po PoMo is not a selective art movement; anything goes. No outright transformation is necessary, just bigger ideas with bigger pockets to fund. ${ }^{174}$ But although a definition of post-postmodernism may seem elusive, Hartness defines these "bigger ideas":

Po PoMo is an art movement founded on the ideal of decadence consisting of big art, artists, and market value. Po PoMo is Postmodernism on steroids. Every aspect of this movement is going far beyond the limits, in regards to taste, style, price, and innovation. And yet this is a movement deeply rooted in the artistic practices of the Postmodernists, such that it may never be clearly defined. ${ }^{75}$

Hartness identifies six "major distinctions" that set post-

73. Paula B. Hartness, "Po Pomo: The Post Postmodern Condition" (Master's thesis, Georgetown University, 2009) in ProQuest Dissertations and Theses, http://ezproxy.lib.ryerson.ca/login?url=http://proquest.umi.com.ezproxy.lib.ryerson.ca/pqdwe $\mathrm{b}$ ?did $=1788283581 \&$ sid $=1 \& \mathrm{Fmt}=6 \&$ clientId $=10120 \& \mathrm{RQT}=309 \& \mathrm{VName}=\mathrm{PQD}$ (accessed April $13,2010), 2-3,10-11$.

74. Ibid., 11.

75. Ibid., 59. 
postmodernism apart from postmodernism. She lists these as: "the rise of art as commodity and artist stars, a focus on galleries, globalization and an increased dissemination of information, a focus on intermedial artistic practices, the overwhelming meta-mentality of artists, and a reemergence of traditional painting and photography." In summary, Hartness calls postpostmodernism a "shinier, newer, Simulacrum" of postmodernism. ${ }^{76}$ The ideas in this list, as they relate to the work of Gregory Crewdson, will be unpacked and examined in greater detail later in this chapter.

In Postproduction Nicolas Bourriaud identifies one of the defining differences between postmodernism and post-postmodernism. He notes that whereas postmodern conceptualists dematerialized artworks, artists of postpostmodernism mix and combine products to generate new meaning. He states, "The art of the twentieth century is an art of montage (the succession of images) and détourage (the superimposition of images),' with détourage becoming the basic mode of function for artists of Post Postmodernism."177 Gregory Crewdson's use of détourage is one important concept that clearly defines him as a post-postmodernist. This will be discussed further later in this chapter.

Hartness calls this culture of remix or postproduction "intermediality," which ties closely to her concept of meta-mentality. Citing works by Sherrie Levine, Jeff Koons, Damien Hirst, and Thomas Ruff, she discusses appropriation, editioning, merchandising, and uniqueness, stating:

76. Hartness, 2, 8.

77. Nicolas Bourriaud, Postproduction (New York: Lukas \& Sternberg, 2002), 42, 45. 
One of the leading theoretical tenets of the Po PoMo era is that there are no new images or forms in art. It makes sense then that artists rework and recontextualize images rather than adding to the plethora of images. Artists take pictures of pictures, incorporate full advertisements into their works or flout copyright laws to make their art. $^{78}$

Photography, Hartness says, is gaining ground in the post-postmodern era, enjoying, in the last twenty years, its "greatest success story." As proof, she cites auction sales, including a Steichen that sold at Sotheby's in 2006 for nearly $\$ 3$ million, and a Gursky that sold at Sotheby's in 2007 for over $\$ 3.3$ million. Hartness explains this increased popularity:

Photography provides viewers the best opportunity to associate what is being represented with what they know. Photographs are easy to read and they do not typically confuse or frustrate the viewer. We can all relate to what is being represented because photographs do not distort the familiar shapes and forms we recognize in reality. Almost everyone has used a camera at least once in his or her life, and the fact that it is universal and common makes photography a readily accepted art form for the masses, even if it was not so readily embraced by the upper echelons of the artworld. ${ }^{79}$

\section{Technological, Social, and Cultural Considerations}

In 1989 the fall of the Berlin Wall signaled the end of the Cold War, and improved communications worldwide. The creation of the European Union in 1993 further promoted easier travel and a sharing of cultures.

A technology boom led to wider and faster access to information, communication, and consumer goods online via the internet, the most defining technological, social, and cultural influence of the post-postmodern era. This new mode of communication and commerce changed galleries' and

78. Hartness, 38.

79. Ibid., 51. 
artists' promotion of themselves and their work, effectively creating a global market.

At the same time, increased access to media and entertainment created a knowledgeable audience for artists. In the article "Tell Me a Story" Lisa Hunter explains, "Our collective knowledge of film culture is similar to the way nineteenth-century audiences were expected to respond to mythological and biblical references-ultimately offering artists a form of visual shorthand. ${ }^{180}$

As society grew accustomed to accessing news and entertainment from the same medium the boundaries between reality and fiction blurred in a "constant flux." ${ }^{181}$ In this age of reality television and infotainment, western society is culturally conditioned to accept this blurring of reality and fiction. Photographic artists of the post-postmodern era are influenced by "docudramas, infomercials, talk shows and tabloid journalism," ${ }^{82}$ as well as art history, film, and the relatively new genre of reality television.

The anger once predicated on such hazy boundaries in the Victorian era, modernism's backlash against pictorialist use of narrative, and postmodernism's need of obvious artifice is now, in the post-postmodern era, replaced by an embrace of uncertainty and ambiguity, as exemplified in the seemingly realistic, yet staged work of Gregory Crewdson. At the same time, as digital means of production became increasingly accessible to consumers and artists alike, the referent came into question even more.

80. Lisa Hunter, "Tell Me a Story," Afterimage 35, no4 (January/February 2008): 3.

81. Pauli, 134.

82. Barbara Pollack, "Lights, Action, Camera!" ARTnews, February 2000, 128. 
As Crewdson's work is exemplary of this uniquely post-postmodern dilemma, discussion of Crewdson's work, his working methodology (notably his use of détourage), the blurring of reality, fiction, and referents will be discussed later in this chapter under the subheading "What Lies Beneath, Reality, and the Real."

\section{The Work of Gregory Crewdson as a Case Study}

Gregory Crewdson completed a three-pronged undergraduate degree majoring in American literature, the history of film, and art photography in 1985, as well as an MFA at Yale in 1988. As a reflection of his diverse education, his cited influences include, in film, David Lynch's Blue Velvet, Steven Spielberg's Close Encounters of the Third Kind, Alfred Hitchcock's Vertigo, as well as television series Twilight Zone and Twin Peaks, books by Stephen King, John Cheever, and Ray Bradbury (Something Wicked This Way Comes), Edward Hopper paintings, and photographers Diane Arbus, Walker Evans, Joel Sternfeld, Lee Friedlander, Robert Frank, William Eggleston, Larry Sultan, Philip-Lorca diCorcia, Cindy Sherman, Nan Goldin, and Stephen Shore. It is my opinion that these oft-cited sources, or influences, in Crewdson's work speak directly to Hartness' expressed notions of the postpostmodern focus on intermedial artistic practices and artists' metamentality.

In the past twenty years Crewdson has produced five distinct bodies of work (all of them staged photography): Natural Wonder (1992-97); Hover (1996-97); Twilight (1998-2002); Dream House (2002); and Beneath the 
Roses (2004-2007). He has taught at Yale since 1993, has had four monographs and one retrospective of his work published, ${ }^{83}$ and is represented by Gagosian in Los Angeles and New York, as well as White Cube in London. Crewdson's international presence, with galleries in different key markets, echoes Hartness' views on the post-postmodern rise of art as commodity, focus on galleries, globalization and increased dissemination. ${ }^{84}$

Crewdson also seems to be benefiting from the photography boom in the market as noted earlier by Hartness. His prints sell for $\$ 75,000$ each at galleries, and fare well at auction, where a print from his latest series, Beneath the Roses, sold at Christie's New York in November 2007 for $\$ 103,000$. The auction record for Crewdson is a 2002 portfolio of twelve prints from The Dream House (commissioned by the New York Times), which sold for $\$ 169,000$ at Sotheby's New York in November $2007 .{ }^{85}$

Though his earliest series, Natural Wonder (1992-97), was produced in-studio as tabletop tableaux, all later works were narrative tableaux shot both in studio and on location. In a methodology now well known, Crewdson employs lighting, actors, location scouts, a director of photography, and a whole host of other crewmembers to produce his increasingly complex works,

83. These are: Rick Moody, et al., Hover: Photographs by Gregory Crewdson (San Francisco: Artspace Books, 1998); Deborah Aaronson, ed., Twilight: Photographs by Gregory Crewdson (New York: Harry N. Abrams, 2003); Stephan Berg, ed., Gregory Crewdson 19852005 (Germany: Hatje Cantz Verlag, 2005); Gregory Crewdson, Gregory Crewdson Fireflies (New York: Skarstedt Fine Art, 2006); and Deborah Aaronson, ed., Beneath the Roses / Gregory Crewdson (New York: Abrams, 2008).

84. See above under "Defining Post-Postmodernism."

2008,

85. Jean Dykstra, "Gregory Crewdson's Twilight Zone," Art and Antiques, October

http://vnweb.hwwilsonweb.com.ezproxy.lib.ryerson.ca/hww/jumpstart.ihtml?recid=0bc05f7a6 7b1790ede70c7893d71e8c1(a3c37cab5318acd66af912fc891be17689a37402829ac5da78fmt $=$ H (accessed March 7, 2010). 
in a process that can take upwards of one week to produce a single image. Perhaps lesser known, Crewdson captures forty or fifty images of a single scene on an $8 \times 10$ inch view camera using film, which are later scanned at high resolution, and combined to create large-scale composite laser direct digital c-prints up to $57 \times 88$ inches. Crewdson says his methodology produces "a kind of clarity: an almost hallucinatory reality, with everything so hyper-real that it becomes almost charged. ${ }^{\prime \prime 6}$

Crewdson's cited film, television, and literary influences, as well as his working methodology of layering and compiling series of images to produce one single final image are important in their relation to Bourriaud's notions of the post-postmodern use of montage and détourage. ${ }^{87}$

The Uncanny, the Aesthetics of Seduction, and the Contemporary Sublime

In the chapter "Once Upon a Time," from her 2009 book the Photograph as Contemporary Art, Charlotte Cotton lists common devices of contemporary photographic tableau: the use of children, obscured faces, play gone awry or turned nasty, literary sources, real-life foundations, a mix of the seductive and abhorrent, and finally a physical beauty in prints in combination with a moral ambiguity of narrative which creates "unnerving visual pleasure." She pinpoints this last element as a dominant trait, particularly in tableau work of the uncanny, where a socially subversive or 2005): 21.

86. Simon James, "A Different Story," British Journal of Photography 152 (May 11,

87. See above under "Defining Post-Postmodernism." 
difficult narrative is cushioned in a rich aesthetic of digitized perfection that is seductive to the eye. ${ }^{88}$

Crewdson uses all of these devices, but key amongst them is his aesthetic. In a 1997 interview with Bradford Morrow, Crewdson says, "I also want the work to have a visceral impact that draws the viewer in through photographic beauty, lushness, vibrant colour. ${ }^{189}$

But this seductive aesthetic, first discussed in Chapter Two, has transformed from postmodernism's familiar, bright, loud, and colourful outdoing of reality through excessiveness (such as that used in advertising, and exemplified in the work of Nagatani) into a dark post-postmodern exploration of the uncanny. The familiar becomes strange, a paradox that both attracts and repels at the same time. Eerie, unsettling, sometimes even described as supernatural in origin or nature, the uncanny, which normally inspires its own rejection, instead seduces the eye with the post-postmodern aesthetic of digitized perfection, even as one is repulsed by subversive or difficult narrative. In his latest series Beneath the Roses Crewdson perfects this paradox of seduction and repulsion, as exemplified in the series' untitled plate 13 (see fig. 6).

88. Charlotte Cotton, "Once Upon a Time," in The Photograph as Contemporary Art, $2^{\text {nd }}$ ed., World of Art (London: Thames and Hudson, 2009), 65-66.

89. Campany, 286. 


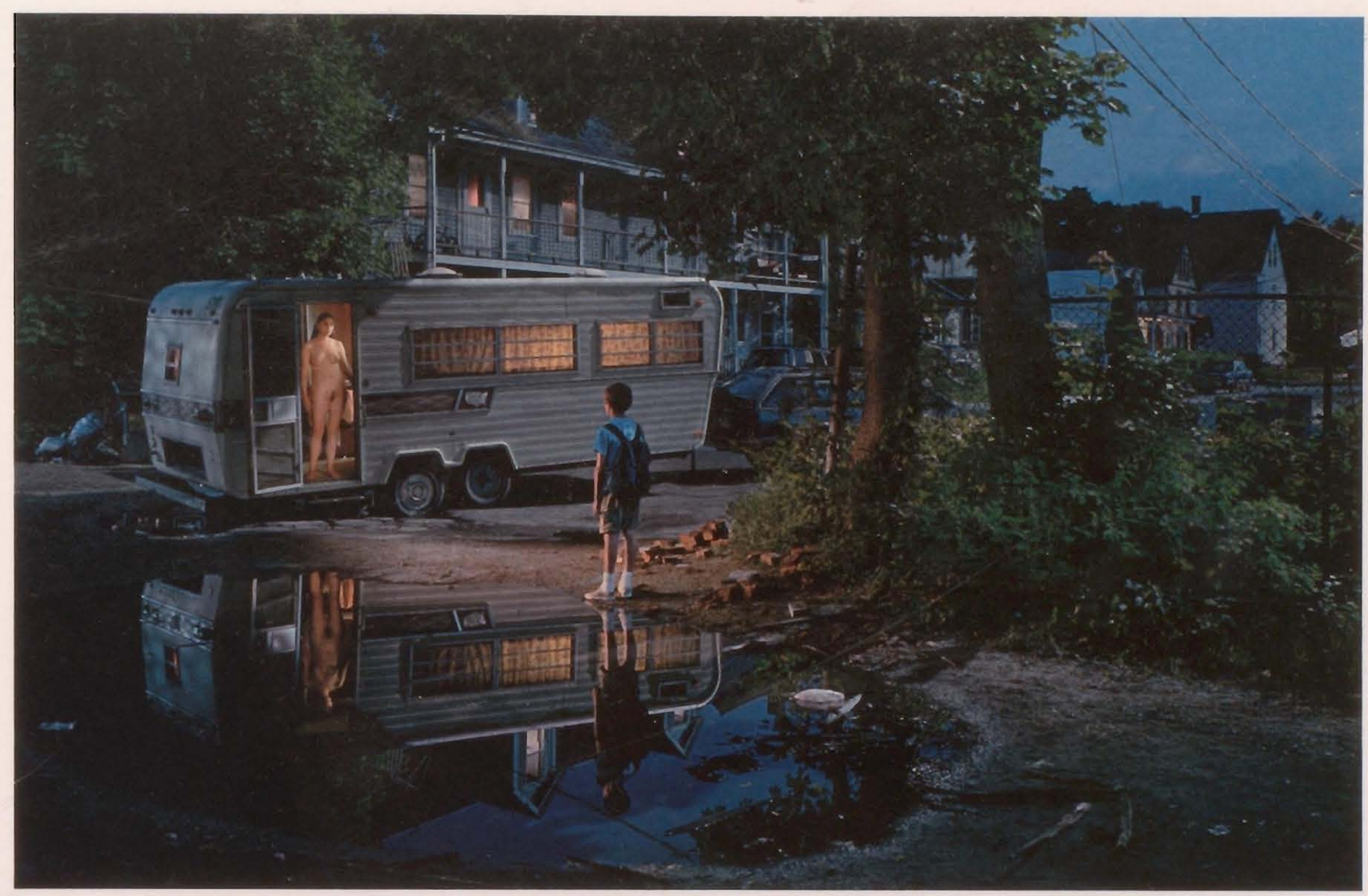

Figure 6. "Untitled (nude woman in trailer)" 2004, (c) Gregory Crewdson. Courtesy Gagosian Gallery.

In his 2003 article "Contemporary Photography and the Recuperation of the Aesthetic Mode" Steven Skopik discusses photographic artists of the 1990s and the use of "over-the-top aesthetic excess" and insistence on "the integrity of the photographic object" as a "renewed willingness to embrace the formal imperatives and seductive descriptive intensity historically associated with classical photographic practices. ${ }^{\prime \prime 0}$

Skopik speaks of Crewdson's work directly, saying he and his contemporaries are "unapologetic advocates of a renewed concern for the sensual-or, dare one say it, beauty." He continues, "They hold out the lure of a highly fetishized formal and descriptive precision, Crewdson's images

90. Steven Skopik, "Contemporary Photography and the Recuperation of the Aesthetic Mode," Exposure 36, no. 1 (2003): 5. 
implicitly endorse a medium-specific aesthetic intimately associated with modernist photographic values and programs." But Skopik is clear to point out these works are not an "anachronistic throwback" as they recognize photographic thought and theory of the last twenty years. And he also notes, they do not have the "austere formal economy" of the modernists, but instead, rather more of a "romantic, Gothic excess." "91

Ultimately, Skopik argues for the existence of a contemporary sublime, which he sees exemplified in Crewdson's work. Defined as "a sobering, even humbling encounter with the ineffable," "an abyss beyond knowing," and "unbounded and fundamentally disillusioning," he sums up the experience of the sublime as "simultaneously compelling and repellent, a moment of nearly rapturous insight accompanied inevitably by a jolt of existential nausea."

Essentially Skopik sees in the work of Gregory Crewdson a merging of two paths in photographic practice-the ambivalence of conceptualism, and the aesthetics of traditional photographic practices-in a way that "delights in the alluring spectacle of classical aesthetics, but bears no illusions regarding the medium's capacities for veracity. ${ }^{\prime 92}$ ?

Crewdson himself has said he wanted to "reconcile" the modern and postmodern in his work, ${ }^{93}$ and interestingly, this discussion of Crewdson's use of the post-postmodern 'new beauty,' 'contemporary sublime,' or 'aesthetics of seduction' does appear to meld modernist aesthetic with postmodernism's self-awareness of the medium's complicated relationship
91. Skopik, 6-7.
92. Ibid., 9.
93. Berg, 85 . 
with the notion of truth. Might this embrace and combination of a modern aesthetic and postmodern theoretical grounding be a useful working definition of the post-postmodern?

Regardless, Crewdson's use of this technique, as well as those discussed below (including antinarrative and the role of the viewer, theatricality, melodrama and metaphor) are all merely means which, when combined, ultimately result in an emblematic expression of photographic representation of truth in the post-postmodern era. Before these expressions of truth can be fully discussed, the techniques by which they are achieved must first be explored.

Antinarrative and The Role of the Viewer

In his introductory essay to Beneath the Roses Russell Banks refers to Crewdson's work as a "story interruptus," as though the images in the series were a sequence, like chapters in a novel, only randomly selected, with parts missing, leaving the viewer to fill in the gaps. In this way, Banks aligns Crewdson's tableaux more with fiction (which requires active participation on the part of the reader to fill in gaps) rather than movies (which often encourage more passive viewing) ${ }^{94}$

Crewdson's own words elaborate on this idea, when he says of his work, "It's an indecisive moment, one between before and after. Something just happened and something's about to happen, but the time connecting

94. Russell Banks, "Gregory Crewdson: Beneath the Roses," in Beneath the Roses / Gregory Crewdson, ed. Deborah Aaronson (New York: Abrams, 2008), 6, 9. 
these moments is the interesting period to me. Time is condensed, in a certain way: impregnated. ${ }^{\prime 95}$ Aside from the more experimental films that work outside the typical narrative form, film, as a time-based medium, differs from the extro-temporal ${ }^{96}$ medium of photography, in which time is stopped, or in the case of Crewdson's work compressed-a trait of the medium Crewdson actively dissects.

Banks calls these works "tableaux mourants," referring to their stillness, and to what is left out. As a "substitute for reality" that stops time, has an "infatuation with the particular," and revels in "incompleteness," where pictures exist in time but with no beginning, middle, or end, Banks says Crewdson's works misrepresent lived actuality, and are in effect "antinarratives." 97

In her exploration of the post-postmodern Hartness says, "It is left to the reader to extrapolate information and meaning based on his own thoughts and experiences. ${ }^{\prime \prime 9}$ Cotton also speaks of this active role taken by the viewer, when she says tableau can "carry an intense but ambiguous drama that is then shaped by the viewer's own trains of thought." She notes it is the easily recognizable construction that makes for a "hyperconscious stance, as we look for narrative form despite the built-in warning signs that

95. James, 25.

96. By which I mean to suggest the notion of photography as outside of, beyond, or removed from time.

97. Banks, 7.

98. Hartness, 16. 
this is a staged, therefore unreal, place. ${ }^{\prime \prime 99}$

In his latest body of work, Beneath the Roses, more obvious

references to Crewdson's influences have been stripped away. Although

physically larger, the images seem to provide less information with which the viewer might create or on to which the viewer might hang an explanatory narrative (see fig. 7), and as such they are left to fill in the gaps and create their own. In this way, Crewdson's work relates to Kirby's concepts of pseudo-modernism whereby cultural production is created or generated wholly or in part by the recipient.

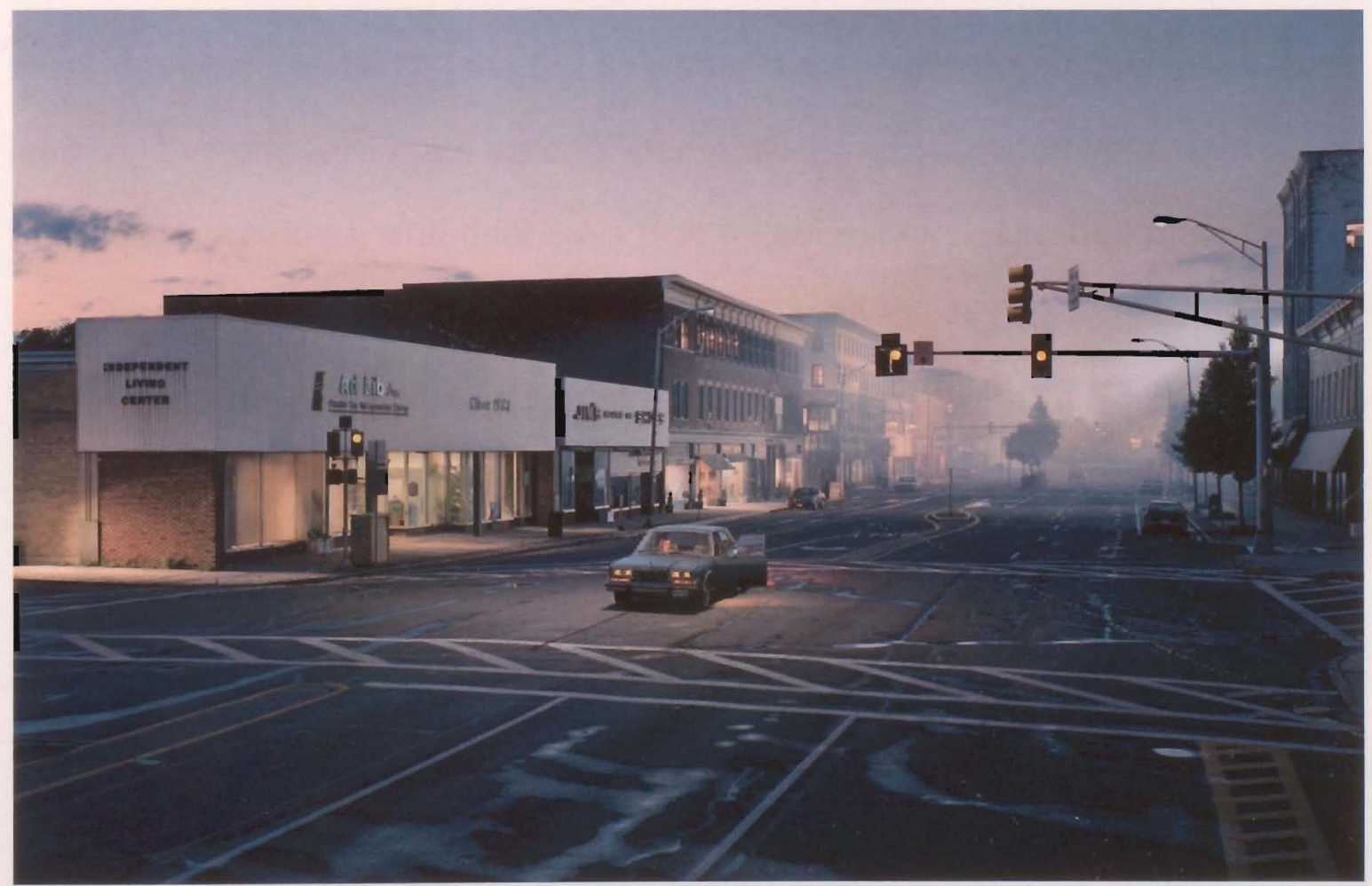

Figure 7. "Untitled (north by northwest)" 2004, (c) Gregory Crewdson. Courtesy Gagosian Gallery.

99. Cotton, 58, 73. 
Echoing Hartness' observations on the embrace of photography in post-postmodern era, Crewdson said he uses photography because "of all the arts it is the most democratic, in so far as it's instantly readable and accessible in our culture. ${ }^{100}$ But he uses the medium in a distinctly theatrical manner, utilizing theatrical constructs such as mirrors, doors, and windows as frames within a frame. As with every other example I have given of Crewdson's work, his images in the later series Beneath the Roses perfects this technique, which runs through much of his earlier work. This may be seen in untitled plate 17 (see fig. 8) where the eye delights in archways that lead to lit rooms with open exterior doors, windows, and stairwells, mirrors that reflect windows, and doorways that reveal mirrors. Untitled plate 20 (see fig. 9) functions in much the same way, with doors that lead to other doors and stairs, or into closets and additional rooms, with mirrored doors, while a wall mounted mirror reflects concealed faces and characters standing in yet more open doorways.

Crewdson discusses this use of mirrors and doorways in the article "In a Lonely Place." He states windows and doorways are framing devices that define space, and are self-referential because they speak to the act of making a photograph. He notes they also suggest voyeurism, providing the viewer an opportunity to peer into a scene through a frame as a silent witness. He goes on to say windows are the "ideal metaphor." Their interior/exterior dynamic suggest loneliness, disconnection, and alienation

100. Campany, 286. 


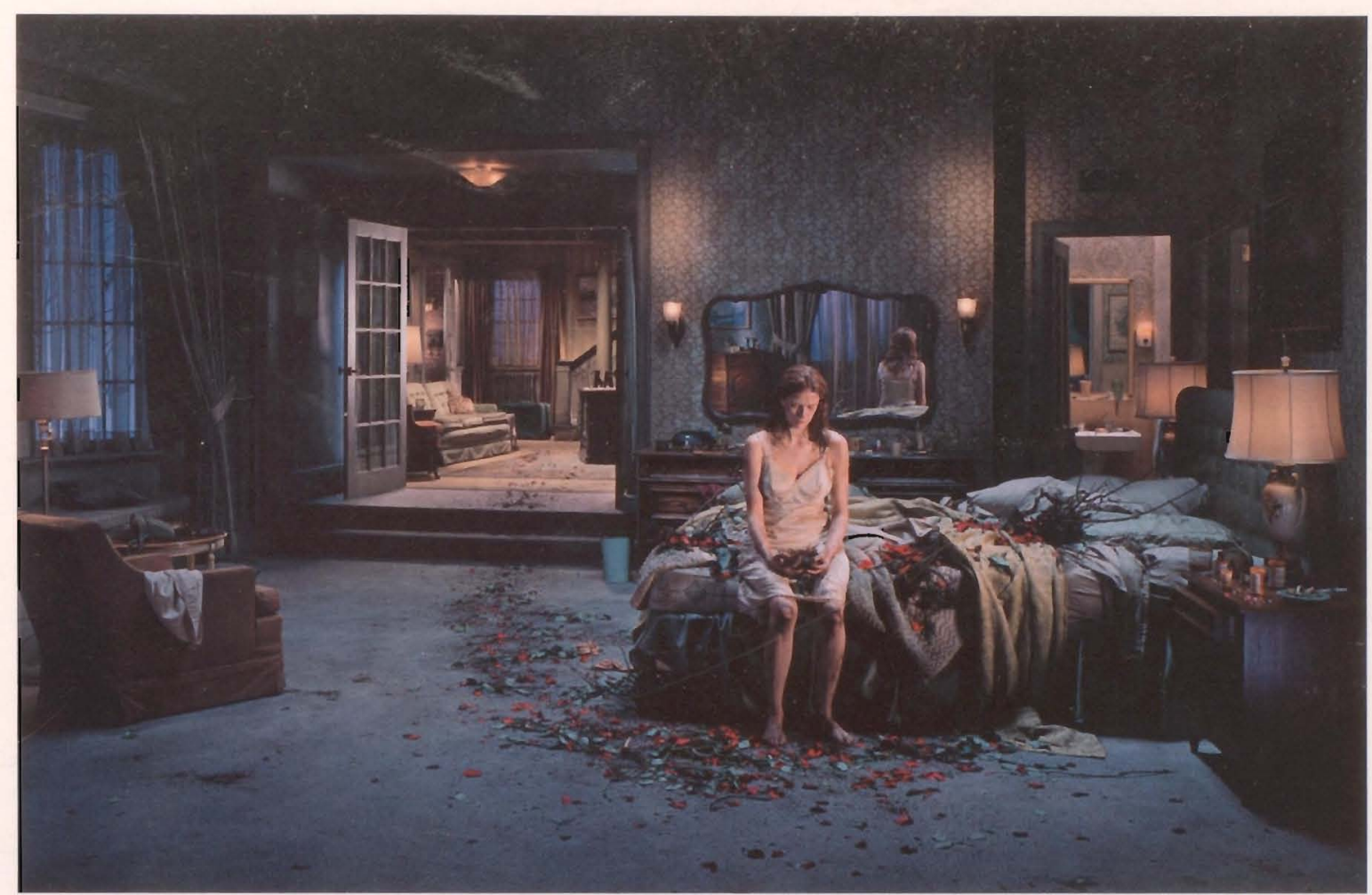

Figure 8. "Untitled (bed of roses)" 2005, (c) Gregory Crewdson. Courtesy Gagosian Gallery.

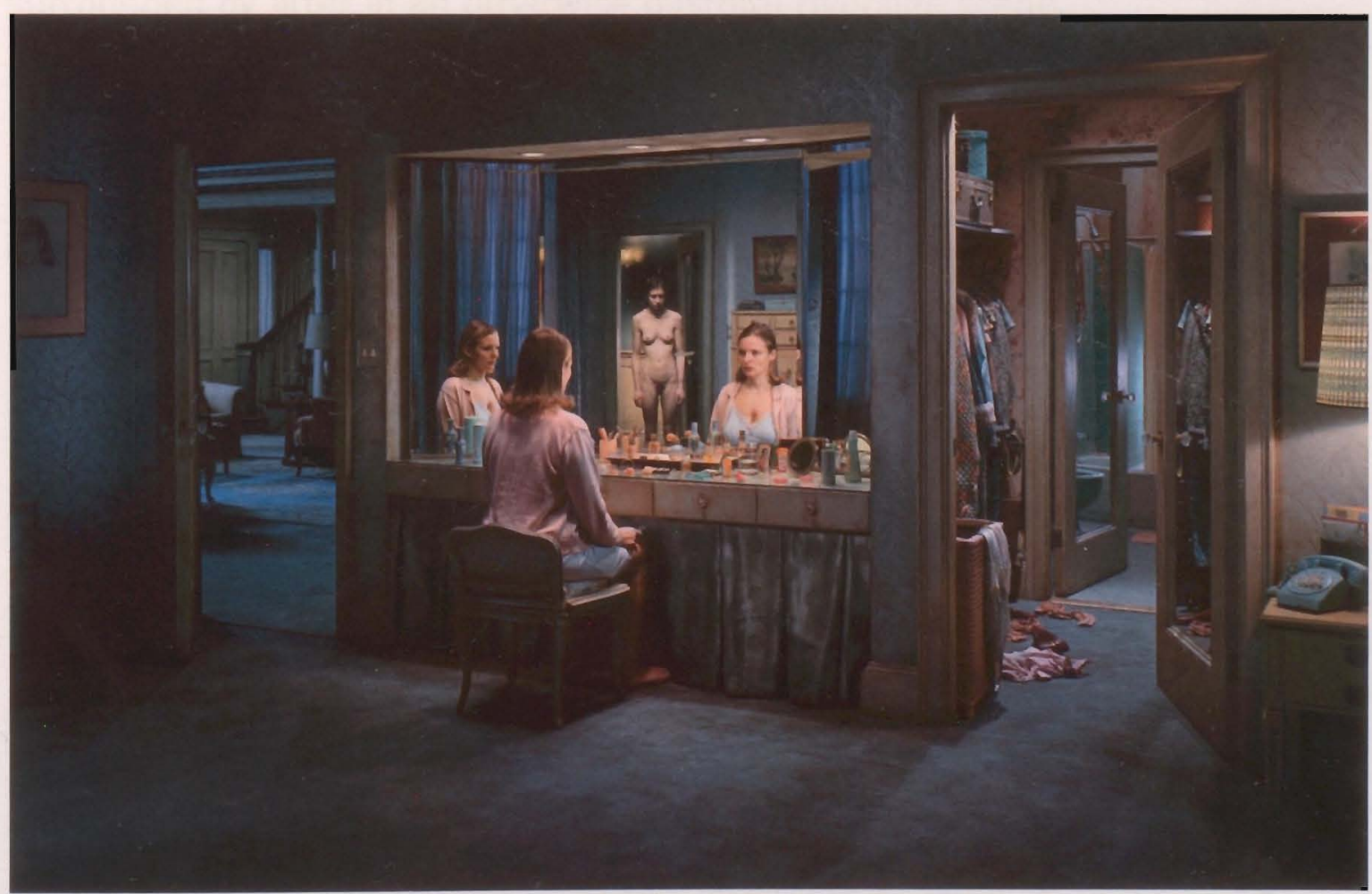

Figure 9. "Untitled (woman at the vanity)" 2004, (c) Gregory Crewdson. Courtesy Gagosian Gallery. 
because they create a division between the subject and the world (or the subject and the viewer), but states they can also suggest possibility and transcendence. Mirrors, he says, imply not only the more obvious selfreflection, but also identity, and isolation from oneself. ${ }^{101}$

In exhibition reviews his work is called "melodramatic" and compared to "soap opera," whereby "place and person settle into melodramatic truce with the encroachments of a distressed landscape and a withering loss of hope and dreams." ${ }^{102}$ Untitled plate 35 from Beneath the Roses is just one of many examples of a post-postmodern Eden gone awry (see fig. 10). In this image an interracial couple, partially dressed and presumably post-coitus, contemplate their lot whilst sitting or lying prone on or near a filthy mattress, surrounded by litter in an otherwise pastoral riverside scene.

Crewdson says he utilizes nature as iconography, and landscape as metaphor for "psychological anxiety, fear or desire." ${ }^{103}$ In a favourite motif, Crewdson brings the outside into the home in untitled plate 17 of Beneath the Roses (see fig. 8), where a woman has presumably dug up and dragged in to the marital bed the remnants of what appears to have been a rose bush.

101. Gregory Crewdson, "In a Lonely Place," Aperture, Spring 2008, http://vnweb.hwwilsonweb.com.ezproxy. lib. ryerson. $\mathrm{ca} / \mathrm{hww} / \mathrm{jumpstart}$.jhtml? recid $=0 \mathrm{bc0}$ $5 \mathrm{fa} 7 \mathrm{6}$ 7b1790ede70c7893d71e8c13c37cab5318acd66c0e34dfbc0e4bca4601d34b28dc8dce9\&fmt $=\mathrm{H}$ (accessed March 7, 2010).

102. Robert Pincus-Witten, review of Gregory Crewdson, by Gregory Crewdson, Luhring Augustine, New York, Artforum, September 2008, 457.

103. Campany, 286. 

audience, stating that like opera, which borrows from fiction, film, theatre, painting, and photography, Crewdson "tests the limits of realism and makes no effort to disguise its artificiality."

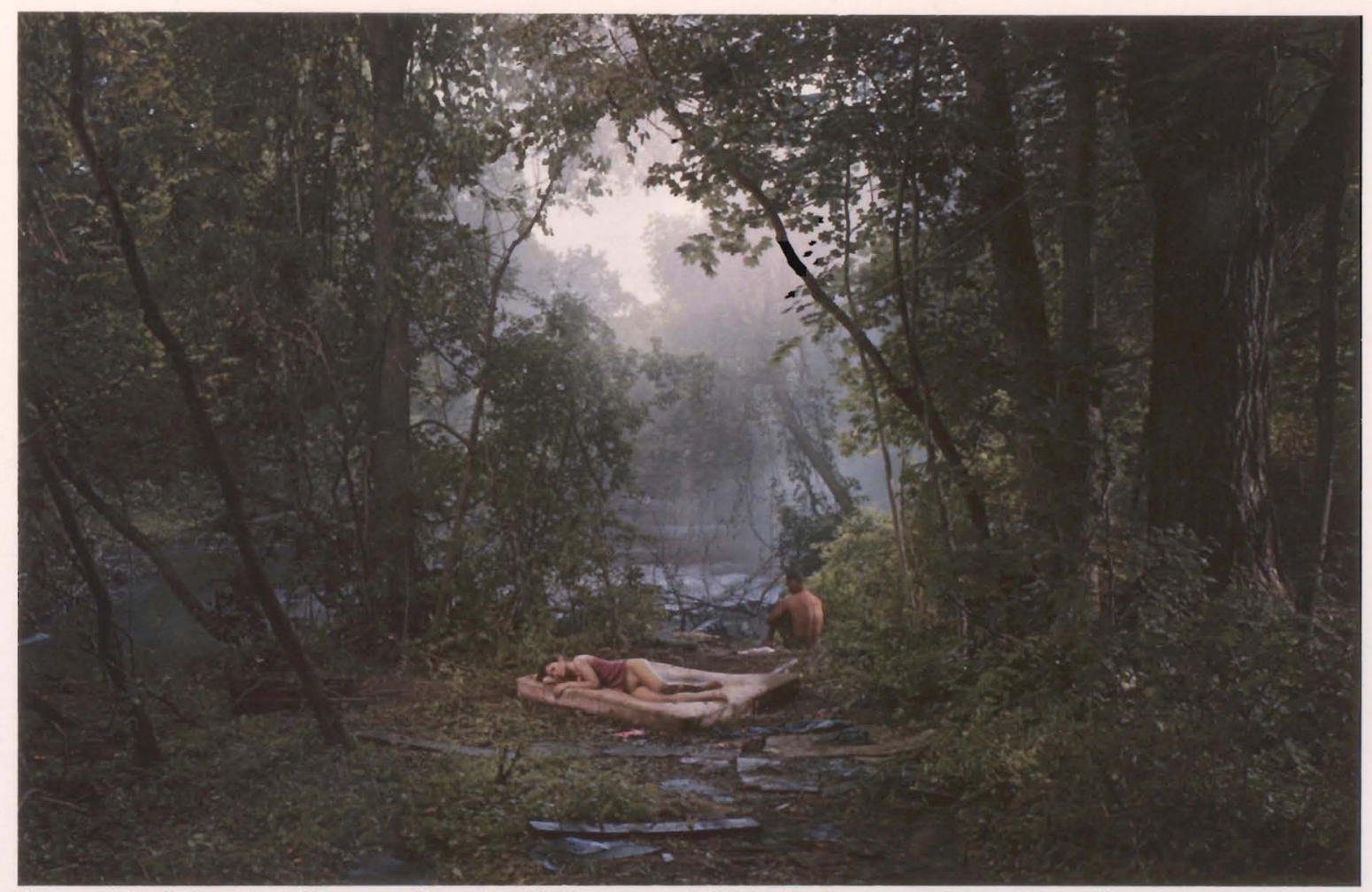

Figure 10. "Untitled (Forest Clearing)" Summer 2006, (c) Gregory Crewdson. Courtesy Gagosian Gallery.

What Lies Beneath, Reality, and the Real

It is often quoted, but nonetheless worth noting that Crewdson's father was a psychoanalyst. Much has been made, or imagined, of Crewdson listening to snippets of dreams and confessions emanating from his father's home office through the floorboards. But the concept of what lies beneath is 
important, not only to Crewdson's work, but to ideas of the postpostmodern. ${ }^{104}$

As Jack Crager says in his article "Beneath the Surface" of Crewdson's work, "His images dive below the placid surfaces of this world to find what dreams lurk beneath." 105

In the essay "The Dark Side of the American Dream" Stephan Berg notes of Crewdson's work:

It is a picture world whose credibility largely derives from its feeling like the sum of all those images of America one has already seen: a reality of the second degree that comes across with the convincingness of primary reality. An illusion that-unlike a copy-is superior to reality in that it recreates and perfects the original. ${ }^{106}$

Crewdson's own words take this further. He says he doesn't agree with references that call his work surreal, stating, "I actually consider myself a realist." He continues, "My pictures can be fantastical, but they're grounded in realism. I like to take ordinary iconography and defamiliarize it and make it mysterious-so there's always a tension between fiction and reality. ${ }^{107}$

Crewdson's seemingly innocuous statement focuses on the crux of the matter, delving beneath the seductive nature of his post-postmodern digitally perfected aesthetic, the extro-temporal nature of his images, and the theatricality of his staging. All these techniques ultimately work towards this

104. On the surface, the idea of what lies beneath can be understood as the narrative tableau artist's use of metaphor or allegory, but digging further into photographic theory it may also be understood as the simulation upon which the post-postmodern image, itself a simulacrum, is based. This theory is outlined and discussed in relation to Crewdson's work in greater detail below.

105. Jack Crager, "Beneath the Surface," American Photo, May/June 2002, 63.

106. Berg, 11.

107. Crager, 63. 
end-the melding of fiction and reality-while at the same time disguising their purpose with their very seductive, disconcerting, and stagey effects. By understanding his use of these techniques it is now possible to discuss Crewdson's use of narrative tableau in relation to the important notion of photographic representations of truth.

To further these discussions it is necessary to examine the influential ideas of French theorist Jean Baudrillard, who made the claim, in The Hyperrealism of Simulation, that "unreality no longer resides in the dream or fantasy, or in the beyond, but in the real's hallucinatory resemblance to itself." 108

Following this, he published the even more influential Simulacra and Simulation. ${ }^{109}$ In this small book he postulated successive phases of the image: a reflection of profound reality (or the image as sacred expression, which I think of as modernism); masking and denaturing a profound reality (or the evil manifestation, which I think of as advertising); masking the absence of a profound reality (where the image is invented or falsified, and validity is questioned-I think of this as the postmodern); and finally, no relation to reality whatsoever (the image as its own pure simulacrum, based on simulation, which I submit as post-postmodern). ${ }^{110}$

108. Jean Baudrillard, "The Hyper-realism of Simulation," in Art In Theory 1900-2000: An Anthology of Changing Ideas, $2^{\text {nd }}$ ed., ed. Charles Harrison and Paul Wood, trans. Charles Levin (Malden: Blackwell, 2003), 1018. This essay was first published as a section of L'Echange symbolique et la mort (in French) in 1976, translated into English in 1984, and reprinted in 1988.

109. Jean Baudrillard, Simulacra And Simulation, trans. Sheila Faria Glaser (Ann Arbor: University of Michigan Press, 1994), bk. This book was first published in French in 1981 , and translated into English in 1994.

110. Baudrillard, Simulacra And Simulation, 12. 
Essentially Baudrillard states the real is not being replaced with another version or interpretation of reality, because a simulacrum no longer has, or never had, an original-the original either no longer exists, or is a copy of a simulation. And the abundance of simulation and simulacra has lead to the creation of a hyper-reality. ${ }^{111}$ Although Baudrillard's ideas address all the eras discussed in this paper, they only really began to influence English-language thinking in the postmodern and post-postmodern eras. ${ }^{112}$ Of the image phases outlined above, it is Baudrillard's final image phase, the image based solely on simulation, which directly relates to Crewdson's work. Crewdson's images are created based on filmic, literary and photographic influences, which are themselves simulations of reality. He also photographs scenes that are fabricated to look more real than reality. Once Crewdson finds a location for a scene, he moves in a massive crew, and with the cooperation of the local population, creates a small town scene with prop cars, incredibly complicated lighting, and weather-making machines which all work in conjunction to create a scene that exists for only one day of photography, before it is completely dismantled. Further to this, as mentioned above, Crewdson takes up to forty or fifty photographs of a single scene which are later combined, utilizing the post-postmodern technique of

111. Patrick A. Hunt, "Shady Acres: Suburbia, Hyper-reality, and Installation Art" (Master's thesis, Webster University, 2007) in ProQuest Dissertations and Theses, http://ezproxy.lib.ryerson.ca/login?url=http://proquest.umi.com.ezproxy.lib.ryerson.ca/pqdwe

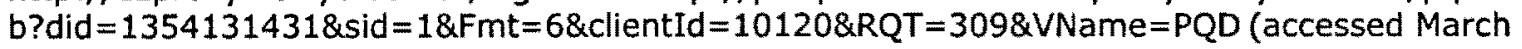
$6,2010), 10-11$.

112. This may perhaps be, in part, because of later publication dates for Englishlanguage translations, released anywhere from eight to thirteen years after the original French-language publications. 
détourage ${ }^{113}$ to create composites of the location, such that even the image is no longer a simulation of the simulation that was constructed to be photographed, but rather something other, something bigger, something more. I submit this is Baudrillard's hyper-reality.

It is because Crewdson's work allows for the consideration and interpretation of such important post-postmodern concepts that he was selected as the case study for the use of photographic narrative tableau of the era. In a review of the Beneath the Roses exhibition in C Magazine in the fall of 2005, writer Terri Whitehead states Crewdson "paradoxically uses illusion to get to what he calls the 'perfect truth. ${ }^{\prime \prime 114}$ of course, we now recognize that simple statement as highly problematic, when Baudrillard argues against the existence of any form of reality in an era when artists like Crewdson construct representations of 'truths' that are simulacrum inspired by, and referring to simulations. In the postmodern era the question was often "whose truth?" but in the post-postmodern era it is now "what truth?"

\section{The Issue of Truth}

In the post-postmodern era western society has embraced the simulacrum as a proxy for the real. Experience is mitigated by mediated images and visual representations. So it is not surprising artists are now

113. Détourage, a superimposition of images, is defined and discussed above in the section "Defining Post-postmodernism, p.43.

114. Terri Whitehead, review of Beneath the Roses, by Gregory Crewdson, White Cube Gallery, London, UK, C Magazine, Fall 2005, 42, http://ezproxy.lib.rverson.ca/login?url=http://proquest.umi.com.ezproxy.lib.ryerson.ca/pgdwe $\mathrm{b}$ ?did $=910951081 \&$ sid $=18 \mathrm{Fmt}=4 \&$ clientId $=10120 \& \mathrm{RQT}=309 \& \mathrm{VName}=\mathrm{PQD}$ (accessed May 11 , 2010). 
creating, and art theorists are now addressing, simulacra based on these simulations. But narrative tableau photography in the post-postmodern era doesn't deny its constructed nature. Instead, by revealing the constructed nature of visual representation it challenges viewers to question its perceived role as a representation of reality or truth. In so doing it reaffirms the possibility of "meaningful representation. ${ }^{115}$ After a lengthy history of questioning the veracity of photographic visual representation, the constructed post-postmodern narrative tableau photograph finally brings the debate full circle, creating wholly realistic photographs that question the veracity of photographs, and in so doing, question the notion of truth. 


\section{Conclusion}

In order to understand the role of photographic narrative tableau in the postmodern and post-postmodern eras, one must become familiar with the history of the genre from its inception. In this thesis, I have used a chronological compare and contrast methodology to grasp changes in the genre, and attribute them to the technological, social and cultural trends of an era. Through this chronological examination it becomes abundantly clear that all narrative tableau photographs, regardless of their era, are irreversibly tangled in concepts of photographic truth and representation.

From debates in 1888 on naturalism versus realism, a cultural acceptance of dressing up and playing for the camera, along with concerns surrounding the veracity of composites, through the influences of both surrealism and Hollywood, to advances in technology that led to a belief in a "decisive moment," and a distrust of staged photography as representative of the real, the idea of truth in representation has never been far from the forefront of discussions on photographic narrative tableau.

The outright rejection of staged photographs, and in particular, narrative tableaux, during the modern era, and postmodernism's later embrace of the genre again posited truth and the representation of reality as the key argument in photographic practice, theory, and criticism. Patrick Nagatani's reinterpretation of historical landmarks, as well as facts, figures and myths generated by the nuclear industry is illustrative of these arguments. His work with narrative tableau photography exemplifies the genre's capacity for illustrating and commenting on events and concepts no 
longer accessible to artists through adherence to modernist strictures and definitions of photographic realism.

Post-postmodernism's embrace of the larger, shinier, technically advanced aesthetic, such as that illustrated by the work of Gregory Crewdson, in combination with important theoretical discourse on the nature of reality in an age of simulation becomes an apotheosis in these questions of narrative tableau's role in the photographic representation of truth. The creation of simulacra by artists like Crewdson has allowed for a questioning of truth, and the representation of reality, on a level heretofore unimaginable. This age of rampant consumerism, globalization, Internet, and digital technologies has created a world whose reality, and subsequent cultural production, is essentially collapsing in upon itself.

The future of narrative tableau in photographic practice, and the everexpanding annals of art history, theory, and criticism, obviously remains to be seen. With this paper, I have endeavoured to illustrate the importance of photographic narrative tableau as a highly significant element, not to be overlooked, in future discussions of the medium's relationship to the problematic concept of truth. 


\section{Bibliography}

\section{History of Staged Photography:}

Brunet, François. Photography and Literature. Exposures, edited by Mark Haworth-Booth and Peter Hamilton. London: Reaktion Books, 2009.

Grundberg, Andy, and Kathleen McCarthy Gauss. Photography and Art: Interactions Since 1946. New York: Abbeville Press, 1987.

Hoy, Anne H. Fabrications: Staged, Altered, and Appropriated Photographs. New York: Abbeville Press, 1987.

Köhler, Michael, ed. Constructed Realities: The Art of Staged Photography. Zurich: Edition Stemmle, 1989.

Pauli, Lori, ed. Acting the Part: Photography as Theatre. London: Merrell, 2006.

Ratcliff, Carter. "Tableau Photography: From Mayall to Rodan, Its Roots and Its Reason." Picture, 1981, 4-19.

Weston, Edward. "Photography-Not Pictorial." Camera Craft 37, no. 7 (1930): 313-320.

\section{Contemporary Art, Theory, and Criticism:}

Baudrillard, Jean. "The Hyper-realism of Simulation." In Art In Theory 19002000: An Anthology of Changing Ideas. $2^{\text {nd }}$ ed., 1018-1020. Edited by Charles Harrison and Paul Wood. Translated by Charles Levin. Malden: Blackwell, 2003.

- - . Simulacra And Simulation. Translated by Sheila Faria Glaser. Ann Arbor: University of Michigan Press, 1994.

Bourriaud, Nicolas. Postproduction. New York: Lukas \& Sternberg, 2002.

Campany, David, ed. Art and Photography. London: Phaidon Press Limited, 2003.

Coleman, A. D. "The Directorial Mode: Notes Toward a Definition." In Light Readings: A Photography Critic's Writings, 1968-1978, 246-257. New York: Oxford University Press, 1979.

Cotton, Charlotte. "Once Upon a Time." In The Photograph as Contemporary Art, $2^{\text {nd }}$ ed., 48-79. World of Art. London: Thames and Hudson, 2009. 
Edwards, Kathleen A. Acting Out: Invented Melodrama in Contemporary Photography. Iowa City: University of Iowa Museum of Art, 2005. Published in conjunction with the exhibition shown at the University of Iowa Museum of Art, and Neuberger Museum of Art.

Grundberg, Andy. Crisis of the Real: Writings on Photography, 1974-1989. Writers and Artists on Photography. New York: Aperture Foundation, 1990.

Hartness, Paula B. "Po Pomo: The Post Postmodern Condition." Master's thesis, Georgetown University, 2009. In ProQuest Dissertations and Theses,

http://ezproxy.lib.ryerson.ca/login?url=http://proquest.umi.com.ezpro xy.lib.ryerson.ca/pqdweb?did $=1788283581 \&$ sid $=1 \& \mathrm{Fmt}=6 \&$ clientId $=1$ 0120\&RQT $=309 \&$ VName $=$ PQD (accessed April 13, 2010).

Hunt, Patrick A. "Shady Acres: Suburbia, Hyper-reality, and Installation Art." Master's thesis, Webster University, 2007. In ProQuest Dissertations and Theses, http://ezproxy.lib.ryerson.ca/login?url=http://proquest.umi.com.ezpro xy. lib.ryerson.ca/pqdweb?did $=1354131431 \&$ sid $=1 \& \mathrm{Fmt}=6 \&$ clientId $=1$ $0120 \& R Q T=309 \&$ VName $=$ PQD (accessed March 6, 2010).

Hunter, Lisa. "Tell Me a Story." Afterimage 35, no. 4 (January/February 2008): 2-3.

Kirby, Alan. Digimodernism: How New Technologies Dismantle the Postmodern and Reconfigure our Culture. New York: Continuum International, 2009.

_- - "The Death of Postmodernism And Beyond." Philosophy Now, 2006. http://www.philosophynow.org/issue58/58kirby.htm (accessed July $16,2010)$.

Kozloff, Max. "Through the Narrative Portal." Artforum, April 1986, 86-97.

Sekula, Allan. "On the Invention of Photographic Meaning." In Photography Against the Grain: Essays and Photo Works, 1973-1983. Halifax: The Press of the Nova Scotia College of Art and Design, 1984. 
Szarkowski, John. "A Different Kind Of Art: To its new public, photography seems to present not only dumb facts but also personal visions." Photography. New York Times 1923-Current file, (April 13, 1975).

http://ezproxy.lib.ryerson.ca/login?url=http://proquest.umi.com.ezpro xy.lib.ryerson.ca/pqdweb?did $=355241902 \&$ sid $=1 \& \mathrm{Fmt}=10$ \&clientId $=1$ $0120 \& R Q T=309 \& V$ Name $=$ HNP (accessed June 23, 2010).

Weber, John S. "Narrative Dimensions in Recent North American Photography." European Photography, October/November/December 1985, 16-18.

\section{Patrick Nagatani}

Center for Creative Photography, University of Arizona. "Patrick Nagatani at The Center for Creative Photography." Traditional Fine Art Online, Inc. http://www.tfaoi.com/aa/2aa/2aa234.htm (accessed May 29, 2010).

Janis, Eugenia Parry. "A Hot Iron Ball He Can Neither Swallow Nor Spit Out: Patrick Nagatani, Nuclear Fear and the Uses of Enchantment." In Nuclear Enchantment: Photographs by Patrick Nagatani, 2-47. Albuquerque: University of New Mexico Press, 1991.

\section{Gregory Crewdson:}

Banks, Russell. "Gregory Crewdson: Beneath the Roses." In Beneath the Roses / Gregory Crewdson, edited by Deborah Aaronson, 6-10. New York: Abrams, 2008.

Berg, Stephan, ed. Gregory Crewdson 1985-2005. Germany: Hatje Cantz Verlag, 2005. Published in conjunction with the exhibition "Gregory Crewdson: 1985-2005" shown at the Kunstverein Hannover, Kunstmuseen Krefeld, Fotomuseum Winterthur, and Landesgalerie Linz.

Crager, Jack. "Beneath the Surface." American Photo, May/June 2002, 62-64.

Gregory Crewdson. Gregory Crewdson Fireflies. New York: Skarstedt Fine Art, 2006. Published in conjunction with the exhibition "Gregory Crewdson Fireflies" shown at Skarstedt Fine Art.

-- . "In a Lonely Place." Aperture, Spring 2008, 78-89. http://vnweb.hwwilsonweb.com.ezproxy.lib.ryerson.ca/hww/jumpstart .jhtml?recid=0bc05f7a67b1790ede70c7893d71e8c13c37cab5318acd6 6c0e34dfbc0e4bca4601d34b28dc8dce9\&fmt $=\mathrm{H}$ (accessed March 7, 2010). 
Dykstra, Jean. "Gregory Crewdson's Twilight Zone." Art and Antiques, October 2008.

http://vnweb.hwwilsonweb.com.ezproxy.lib.ryerson.ca/hww/jumpstart .jhtml?recid=0bc05f7a67b1790ede70c7893d71e8c1 (a3c37cab5318acd 66 af912fc891be17689a37402829ac5da7\&fmt =H (accessed March 7, 2010).

James, Simon. "A Different Story." British Journal of Photography 152 (May 11, 2005): 20-25.

Moody, Rick. "Gregory Crewdson." In Twilight: Photographs by Gregory Crewdson, edited by Deborah Aaronson, 6-11. New York: Harry N. Abrams, 2002. Published in conjunction with gallery exhibitions shown at Luhring Augustine, New York, Gagosian, Los Angeles, and White Cube, London.

- - , Darcey Steinke, Joyce Carol Oates, and Bradford Morrow. Hover: Photographs by Gregory Crewdson. San Francisco: Artspace Books, 1998.

Pincus-Witten, Robert. Review of Gregory Crewdson, by Gregory Crewdson, Luhring Augustine, New York. Artforum, September 2008, 457.

Pollack, Barbara. "Lights, Action, Camera!" ARTnews, February 2000, 126 -131 .

Skopik, Steven. "Contemporary Photography and the Recuperation of the Aesthetic Mode." Exposure 36, no. 1 (2003): 3-9.

Whitehead, Terri. Review of Beneath the Roses, by Gregory Crewdson, White Cube Gallery, London, UK. C Magazine, Fall 2005, 42.

http://ezproxy.lib.ryerson.ca/login?url=http://proquest.umi.com.ezpro xy.lib.ryerson.ca/pqdweb?did $=910951081 \&$ sid $=1 \& \mathrm{Fmt}=4 \&$ clientId $=10$ $120 \&$ RQT $=309 \&$ VName $=P Q D$ (accessed May 11, 2010). 